Article

\title{
Anti-Tick-Borne Encephalitis Virus Activity of Novel Uridine Glycoconjugates Containing Amide or/and 1,2,3-Triazole Moiety in the Linker Structure
}

\author{
${\text { Gabriela Brzuska }{ }^{1} \text {, Gabriela Pastuch-Gawolek }}^{2,3}{ }^{\circledR}$, Monika Krawczyk ${ }^{2,3}{ }^{(}$, \\ Boguslaw Szewczyk ${ }^{1}$ (D) and Ewelina Krol ${ }^{1, *(D)}$ \\ 1 Department of Recombinant Vaccines, Intercollegiate Faculty of Biotechnology, University of Gdansk and \\ Medical University of Gdansk, Abrahama 58, 80-307 Gdansk, Poland; \\ gabriela.brzuska@phdstud.ug.edu.pl (G.B.); boguslaw.szewczyk@biotech.ug.edu.pl (B.S.) \\ 2 Department of Organic Chemistry, Bioorganic Chemistry and Biotechnology, Faculty of Chemistry, \\ Silesian University of Technology, Krzywoustego 4, 44-100 Gliwice, Poland; \\ gabriela.pastuch@polsl.pl (G.P.-G.); monika.krawczyk@polsl.pl (M.K.) \\ 3 Biotechnology Centre, Silesian University of Technology, Krzywoustego 8, 44-100 Gliwice, Poland \\ * Correspondence: ewelina.krol@biotech.ug.edu.pl; Tel.: +48-58-523-63-83
}

Received: 30 November 2020; Accepted: 11 December 2020; Published: 13 December 2020

check for updates

\begin{abstract}
Tick-borne encephalitis virus (TBEV) transmitted by ticks is a pathogen of great medical importance. As still no effective antiviral treatment is available, in the present study, a series of uridine glycoconjugates containing amide or/and 1,2,3-triazole moiety in the linker structure was synthesized and evaluated for the antiviral activity against two strains of TBEV: a highly virulent Hypr strain and less virulent Neudoerfl strain, using standardized previously in vitro assays. Our data have shown that four compounds from the series (18-21) possess strong activity against both TBEV strains. The half maximal inhibitory concentration $\left(\mathrm{IC}_{50}\right)$ values of compounds 18-21 were between 15.1 and $3.7 \mu \mathrm{M}$ depending on the virus strain, which along with low cytotoxicity resulted in high values of the selectivity index (SI). The obtained results suggest that these compounds may be promising candidates for further development of new therapies against flaviviruses.
\end{abstract}

Keywords: uridine glycoconjugates; antiviral activity; glycosyltransferase inhibitors; flavivirus; tick-borne encephalitis virus

\section{Introduction}

As the present pandemic situation shows, emerging viral infections cause many adverse effects, not only directly on human health, but also on all aspects of our lives. One of such potential dangers of viral origin are flaviviruses possessing positive-sense RNA genomes. Many viruses of the Flaviviridae family are associated with human diseases of great medical importance. In the past few decades flaviviruses, due to the climate change, have tremendously widened their range and have longer periods of activity, resulting in over 400 million infections per year, due to which they are a constant threat to public health [1]. Flaviviruses infect not only humans, but also many other animal hosts, like birds, rodents, non-human primates and many other mammals. Their transmission is highly correlated with the expansion of the geographical range of their insect vectors-ticks and mosquitos. Recently, many epidemics and outbreaks of emerging and re-emerging flaviviruses (such as Zika virus (ZIKV), dengue virus (DENV), yellow fever virus (YFV) or West Nile virus (WNV)) have been observed, which has raised the importance of the research concerning treatment and prevention methods [2-4]. 
Within the group of tick-transmitted viruses, tick-borne encephalitis virus (TBEV) is one of the most pathogenic flaviviruses affecting the human central nervous system. It causes a seasonal disorder called tick-borne encephalitis (TBE), which may lead to severe and long-lasting complications including meningitis, meningoencephalitis, partial paralysis, coma or even death [5]. TBEV is endemic in over 30 countries of Europe and Asia and new endemic centers are constantly reported [6]. In these regions several TBEV subtypes are circulating, with three main subtypes: European (TBEV-Eu), Siberian (TBEV-Sib), Far Eastern (TBEV-FE) and two newly discovered: Baikalian (TBEV-Bkl) and Himalayan (TBEV-Him) $[7,8]$. These subtypes differ not only in the geographical distribution, which depends on their tick vector (Ixodes ricinus-TBEV-Eu, Ixodes persulcatus-TBEV-FE and TBEV-Sib), but most importantly in the severity of the TBE course and fatality rate. A bite of an TBEV infected tick is the most common route of human infection; however, other routes like consumption of unpasteurized milk or milk products from infected ruminants are also possible [9]. Although few vaccines against TBEV are on the market, vaccination is not mandatory in most of the affected countries resulting in around 13,000 annual cases worldwide [6,10]. Moreover, up to this date no effective and licensed treatment for TBEV infection is available, although different antiviral compounds are being tested in the laboratories [11-14]. For the treatment of infected patients, the only strategy being implemented in hospitals is to alleviate the symptoms. In light of these facts, the research on the new antiviral drugs is highly justified.

From the structural point of view, members of the Flavivirus genus share several morphological similarities. TBEV is a small, enveloped virus with a mean diameter of $50 \mathrm{~nm}$. The genome, surrounded by the capsid $(C)$ is in the form of a ssRNA $(+)$, which encodes a single polyprotein cleaved to three structural: C, prM/M, E and five non-structural proteins (NS1-5) [15]. The prM/M and E proteins are anchored in the envelope of the virus. The role of the E protein in the TBEV cycle is well characterized. It mediates entry via receptor mediated endocytosis, and contains the major antigenic epitopes used for generation of protective immune response [16]. Three of the flaviviral proteins usually possess at least one $\mathrm{N}$-glycosylation site: prM, E and NS1 and these proteins play a crucial role during the virion assembly and maturation, entry to the cells, immune evasion and replication. The role of glycans in the flavivirus replication cycle is not fully understood. For TBEV, it has been shown that removal of the glycosylation site in the E protein leads to the reduction in infectivity of secreted virions [17]. Therefore, it is important to examine the role of glycans in each flavivirus infection separately and to test the activity of glycosylation inhibitors as potential antiviral drugs.

Various glycosyltransferases (GT) may be utilized by flaviviruses to attach specific glycans onto their proteins. Inhibition of one of the GT with synthetic compounds may be a promising strategy for antiviral treatment for different flaviviruses. Previously, we have shown the antiviral activity of different uridine derivatives targeting GT against members of the Flaviviridae family-classical swine fever virus (CSFV), hepatitis C virus (HCV), and also against TBEV [18-20]. Moreover, the activity of these compounds was tested against influenza virus (Orthomyxoviridae family member) [21]. The inhibitory effect of these compounds was associated with the impaired maturation and secretion of infectious viruses. These studies showed that GT inhibitors could be used as broad-spectrum antiviral drugs against different human and animal viruses.

In this study, we present the design, synthesis and antiviral activity of a novel type of uridine glycoconjugates, containing amide or/and 1,2,3-triazole moiety in the linker structure, against two strains of tick-borne encephalitis virus, a main cause of human neuroinfections.

\section{Results}

\subsection{Synthesis of Glycoconjugates 13-23}

We designed compounds that can compete with natural glycosyltransferase substrates for sites in their active centers. As previously published, natural donor-type substrates contain in their structure a sugar unit linked via a diphosphate moiety to uridine [22,23]. Conventional modification methods of glycosyltransferase inhibitors may include the replacement of the diphosphate moiety and connection of the 
sugar unit via a non-charged linker to the uridine part. Such a linker should be capable of coordinating the divalent metal ion (usually magnesium or manganese) bound in the active site of the enzyme. In the tested glycoconjugates, the diphosphate moiety was replaced with an amide linker between carbohydrate and uridine moiety (glycoconjugate structure type I, Figure 1) or with a methylene 1,2,3-triazolyl part linked to a sugar or uridine moiety via an amide or ether linkage (glycoconjugate structures types II-IV, Figure 1). Recently, the results of studies showing that a completely deprotected type IV glycoconjugate is able to inhibit the activity of $\beta$-1,4-galactosyltransferase I ( $\beta 4 \mathrm{GalT})$ were reported [24]. There are also reports of the synthesis of a (triazolyl) methyl amide-linked disaccharide nucleosides as analogues of nucleoside diphosphate sugars. Some of the obtained $6^{\prime}$-isonucleosides and triazole-containing glycoderivatives displayed acetylcholinesterase inhibitory activities [25]. Nucleoside triphosphate mimetic, where the phosphate residues-containing chain was replaced by an uncharged methylene-triazole moiety, are also known to have occurred. These compounds have been evaluated as competitive inhibitors of Bacillus anthracis pantothenate kinase [26]. Therefore, it can be assumed that the 1,2,3-triazole ring in the linker structure is an important element for glycoconjugate activity. The aim of the present work was to investigate the influence of the linker structure containing the 1,2,3-triazole system on the biological activity of the obtained connections. Glycoconjugates structure type III have the reverse direction of linking reactive moieties (as a result of the reaction between sugar azides and 5'-propargyl uridine derivative) compared to the glycoconjugate structure type IV. In turn, in the glycoconjugate structure of type II, an additional amide moiety was introduced between the methylene 1,2,3-triazolyl part and uridine compared to the structure type III. It was presumed that insertion into a linker of an additional amide bond, the presence of which is observed in many biologically active compounds should improve glycoconjugates' chelating ability, and thus their binding ability at the metal-dependent enzyme active center [27].

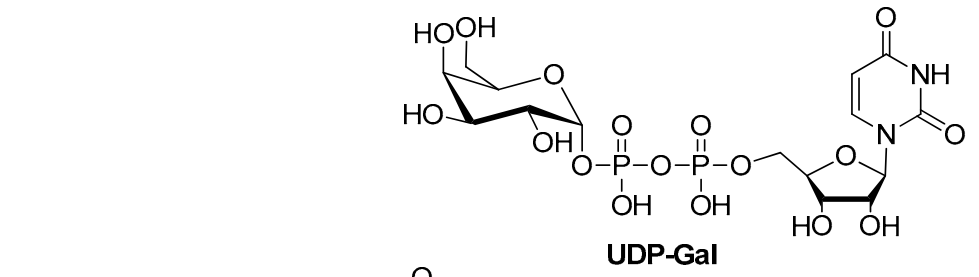

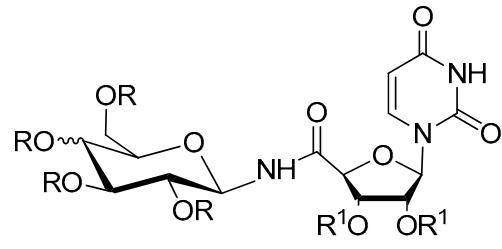

Glycoconjugate structure type I

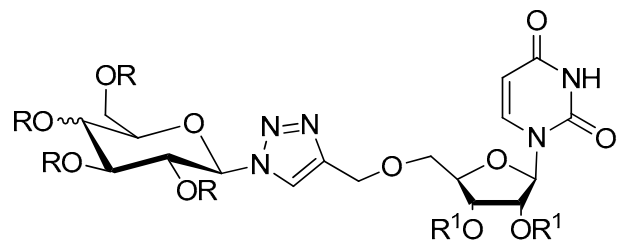

Glycoconjugate structure type III

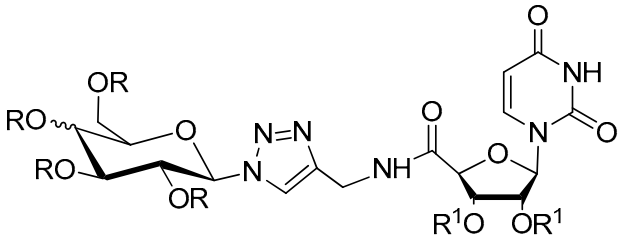

Glycoconjugate structure type II

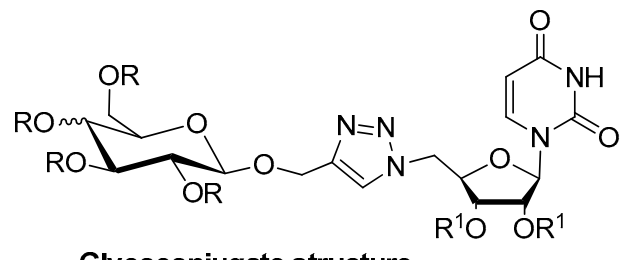

Glycoconjugate structure type IV

Sugar unit: D-Glucose or D-Galactose $\mathbf{R}$ : Ac or $\mathrm{Bn}$

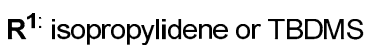

Figure 1. The general structures of glycoconjugates, analogues of the natural $\beta 4$ GalT substrate-UDP-Gal.

The key reactions to obtain the planned glycoconjugate structures are the condensations between the amine and carboxyl derivatives leading to the formation of an amide bond as well as copper-catalyzed 1,3-dipolar azido-alkyne cycloaddition to form a 1,2,3-triazole system. Therefore, 
it was necessary to prepare appropriate sugar and uridine derivatives, which were then be used in the synthesis of glycoconjugates.

The first part of the synthesis was devoted to the sugar building blocks necessary for glycoconjugates synthesis. The synthetic pathways leading to the formation of sugar derivatives are presented in Scheme 1. All substrates were prepared according to the previously published procedures involving the acetylation of free sugars $\mathbf{1 a}$ or $\mathbf{2} \mathbf{a}$ and conversion of per-O-acetylated derivatives $\mathbf{1} \mathbf{b}$ or $\mathbf{2} \mathbf{b}$ into the corresponding glycosyl bromides 1 c or 2c [22,28]. The glycosyl bromides were used immediately for further reactions leading to obtain 2,3,4,6-tetra-O-acetyl- $\beta$-glycosyl azides 1 and 2 [23]. To obtain glucosyl azide 5a with benzyl protecting groups, it was necessary to remove the acetyls from compound $\mathbf{1}$ under Zemplén conditions [29] which allowed the attainment of deprotected $\beta$-glycosyl azide which was benzylated with benzyl bromide in the presence of sodium hydride in anhydrous DMF [30]. $\beta$-D-Glycopyranosyl amines 3-5 were obtained from the corresponding glycosyl azides 1, 2 or 5a through a hydrogenation reaction in a Parr apparatus using palladium hydroxide deposited on activated carbon [31].

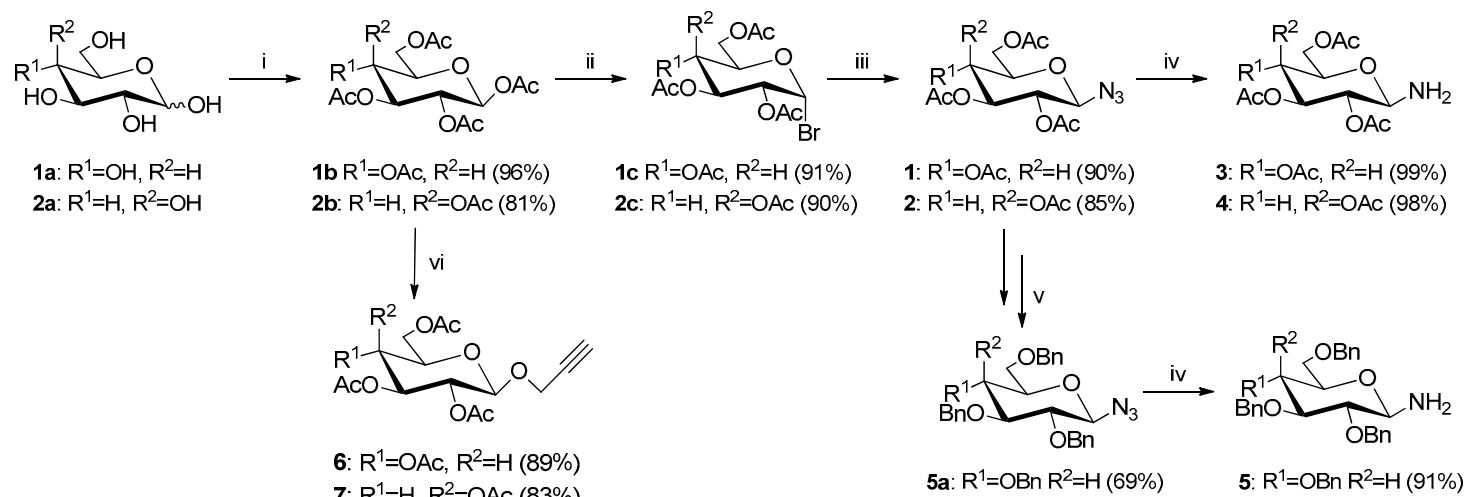

Scheme 1. Synthesis of sugar derivatives. Reagents and conditions: (i) $\mathrm{CH}_{3} \mathrm{COONa}, \mathrm{Ac}_{2} \mathrm{O}$, b.p., 1 h; (ii) $\mathrm{CH}_{3} \mathrm{COOH}, 33 \% \mathrm{HBr} / \mathrm{AcOH}$, r.t. 1 h; (iii) $\mathrm{NaN}_{3}$, TBASH, $\mathrm{CHCl}_{3} / \mathrm{NaHCO}_{3}$, r.t. 2 h; (iv) $20 \%$ $\mathrm{Pd}(\mathrm{OH})_{2} / \mathrm{C}$, THF:EtOH (2:1, v/v), $\mathrm{H}_{2}, 1.5$ bar, 2 h; (v) 1. NaOMe, MeOH, r.t. 20 min; 2. Amberlyst-15, 3. $\mathrm{BnBr}, \mathrm{NaH}, \mathrm{DMF}$, r.t., $24 \mathrm{~h}$; (vi) propargyl alcohol, $\mathrm{BF}_{3} \cdot \mathrm{Et}_{2} \mathrm{O}, \mathrm{CH}_{2} \mathrm{Cl}_{2}$, r.t., 1 h.

Sugar derivatives 6 and 7 in which the alkynyl moiety was introduced were prepared by reacting per-O-acetylated D-glucose $\mathbf{1 a}$ or D-galactose $\mathbf{1} \mathbf{b}$ with propargyl alcohol in the presence of a Lewis acid as a catalyst [32]. The acetyl neighboring-group participation at the C-2 position of the sugar ensured the formation of only products of the $\beta$-configuration. As a result, propargyl 2,3,4,6-tetra-O-acetyl- $\beta$-D-glycopyranosides 6 and 7 were obtained with good yields (89\% and $83 \%$, respectively).

The synthesis of uridine derivatives 8-10, a second component necessary for the construction of glycoconjugates, as well as compounds 11a and 12a were described in the earlier works of our group [18,24]. The counterpart of uridine derivative 10 with TBDMS-protecting groups was obtained by adding propargyl amine to the compound 11a using DCC as an amide coupling agent (Scheme 2) [33]. The product 11 was obtained in the form of a colorless oil with a yield of $75 \%$.

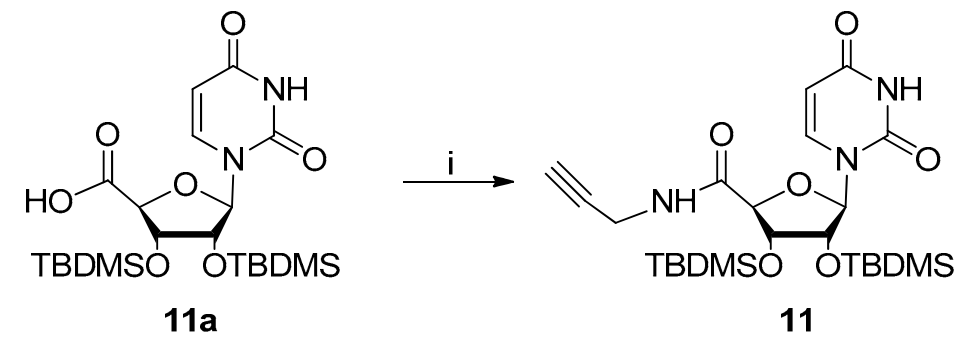

Scheme 2. Synthesis of uridine derivative 11. Reagents and conditions: (i) propargylamine, DCC, $\mathrm{CH}_{2} \mathrm{Cl}_{2}$, r.t, 24 h. 
The last uridine derivative was obtained by reacting compound 12a with propargyl bromide in anhydrous tetrahydrofuran using sodium anhydride as a base (Scheme 3). Carrying out the reaction in an ultrasonic bath increases the contact surface of the reactants, and thus accelerates the reaction. Thanks to the procedure used, the product 12 was obtained with a yield of $59 \%$.

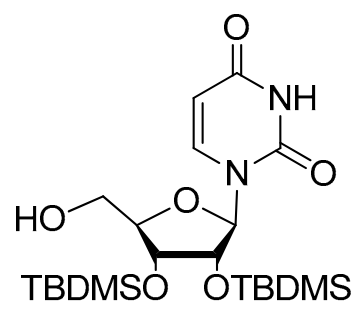

$12 a$

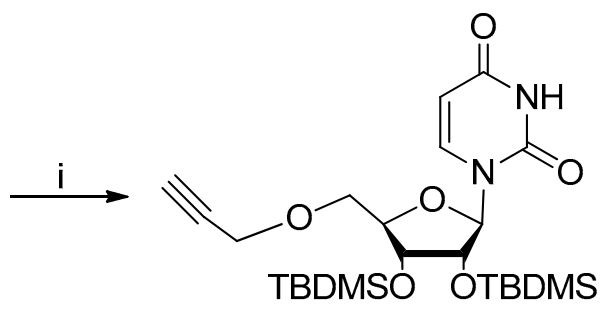

12

Scheme 3. Synthesis of uridine derivative 12. Reagents and Conditions: (i) propargyl bromide, NaH, THF, r.t., ultrasonic bath, $4 \mathrm{~h}$.

The synthesis of glycoconjugates was started with glycoconjugates 13-15 which were obtained in the condensation reaction between 1-aminosugars 3-5 and uridine derivative 8 as an acid donor, using generated in situ an amide coupling agent (4-(4,6-dimethoxy[1,3,5]triazin-2-yl)-4-methylmorpholinium chloride) (DMTMM). The procedure worked well for glycoconjugates $\mathbf{1 3}$ and $\mathbf{1 4}$ obtained from acetyl protected sugar derivatives (80\% and 86\% yield respectively, Scheme 4), however in the case of 1-aminosugar with benzyl protection, it was possible to obtain glycoconjugate $\mathbf{1 5}$ only with a moderate yield $(42 \%)$. A possible explanation for this may be the excessively high reactivity of the amino sugar with electron-donating protecting groups, which leads to the formation, in addition to the desired glycoconjugate, also of by-products. Indeed, the spots, not only from the formed glycoconjugate, but also from other sugar-containing products were observed on the thin layer chromatography (TLC) plates used to follow the reaction progress.

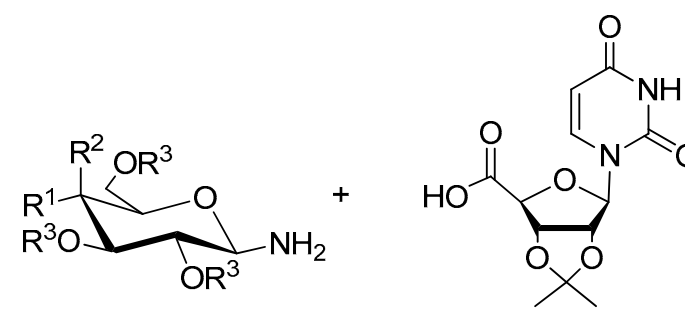

3: $\mathrm{R}^{1}=\mathrm{OAC}, \mathrm{R}^{2}=\mathrm{H}, \mathrm{R}^{3}=\mathrm{Ac}$

4: $R^{1}=H, R^{2}=O A c, R^{3}=A c$

5: $\mathrm{R}^{1}=\mathrm{OBn}, \mathrm{R}^{2}=\mathrm{H}, \mathrm{R}^{3}=\mathrm{Bn}$

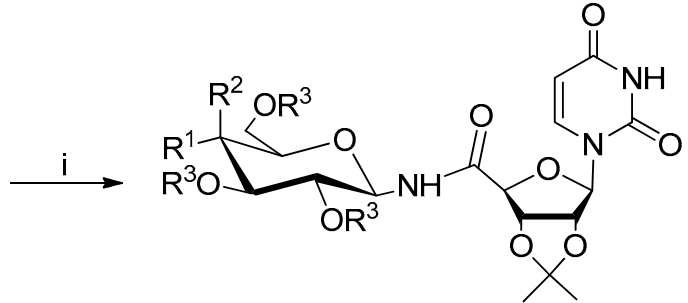

13: $R^{1}=O A C, R^{2}=H, R^{3}=A c,(80 \%)$

14: $R^{1}=H, R^{2}=O A c, R^{3}=A c,(86 \%)$

15: $R^{1}=O B n, R^{2}=H, R^{3}=B n,(42 \%)$

Scheme 4. Synthesis of glycoconjugates type I. Reagents and conditions: (i) CDMT, NMM, MeOH, r.t., 5 h.

Other glycoconjugates, which were assumed to have a 1,2,3-triazole system in the linker structure between the sugar fragment and uridine, were obtained using copper-catalyzed azide-alkyne 1,3-dipolar cycloaddition (CuAAC) [34,35]. For the preparation of glycoconjugates 16-19 CuAAC reactions between 1-azido sugars $\mathbf{1}$ or $\mathbf{2}$ and uridine derivatives $\mathbf{1 0}$ or $\mathbf{1 1}$ were performed (Scheme 5). As the result of the reactions, glycoconjugates 16-19 were obtained with good yields. In order to be able to assess whether the amide bond introduced into the linker structure has a significant influence on the biological activity of the final compounds, glycoconjugates $\mathbf{2 0}$ and $\mathbf{2 1}$ were prepared in parallel in which the amide bond in the uridine fragment has been replaced with a linkage via an oxygen atom. 


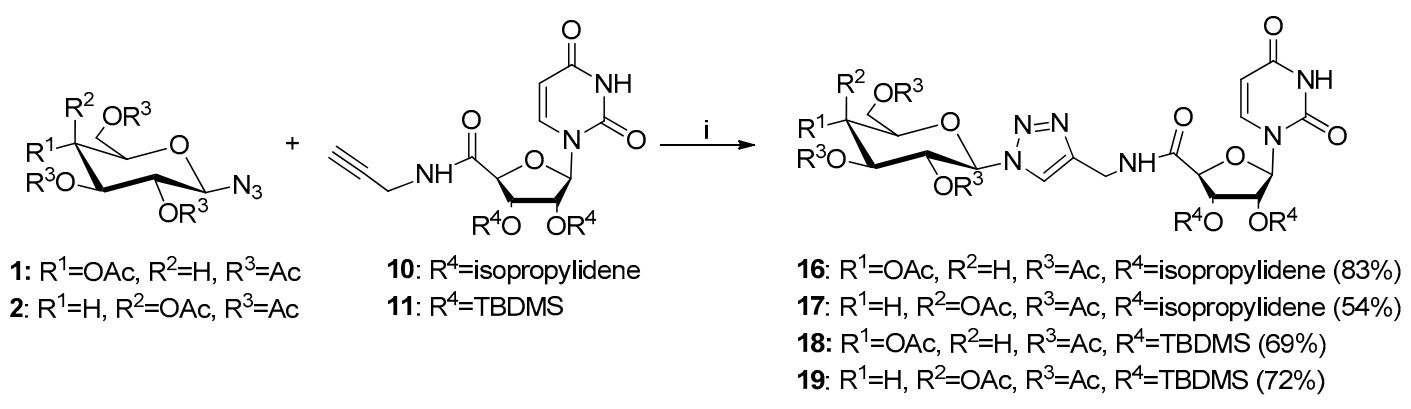

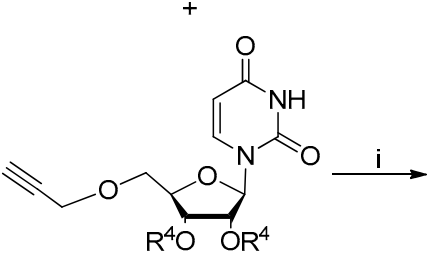

12: $R^{4}=T B D M S$

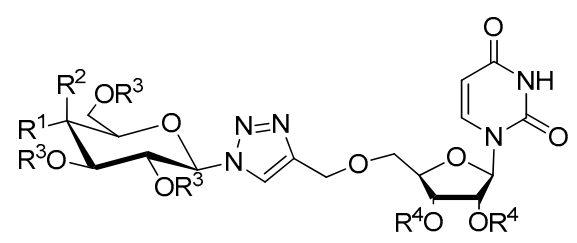

20: $R^{1}=O A c, R^{2}=H, R^{3}=A c, R^{4}=$ TBDMS $(72 \%)$

21: $R^{1}=H, R^{2}=O A c, R^{3}=A c, R^{4}=$ TBDMS $(74 \%)$

Scheme 5. Synthesis of glycoconjugates type II and type III. Reagents and Conditions: (i) $\mathrm{CuSO}_{4} \cdot 5 \mathrm{H}_{2} \mathrm{O}$, $\mathrm{NaASC}, \mathrm{THF} / i-\mathrm{PrOH}, \mathrm{H}_{2} \mathrm{O}$, r.t.

The last group of type IV glycoconjugates was obtained in order to check whether the reverse orientation of the 1,2,3-triazole system in the linker structure has a significant influence on the biological activity of these connections. In case of the synthesis of glycoconjugates 22 and 23, propargyl glycosides 6 and 7 and the uridine derivative 9 containing an azide moiety in the $C-5^{\prime}$ position were used as substrates for the CuAAC reaction (Scheme 6).

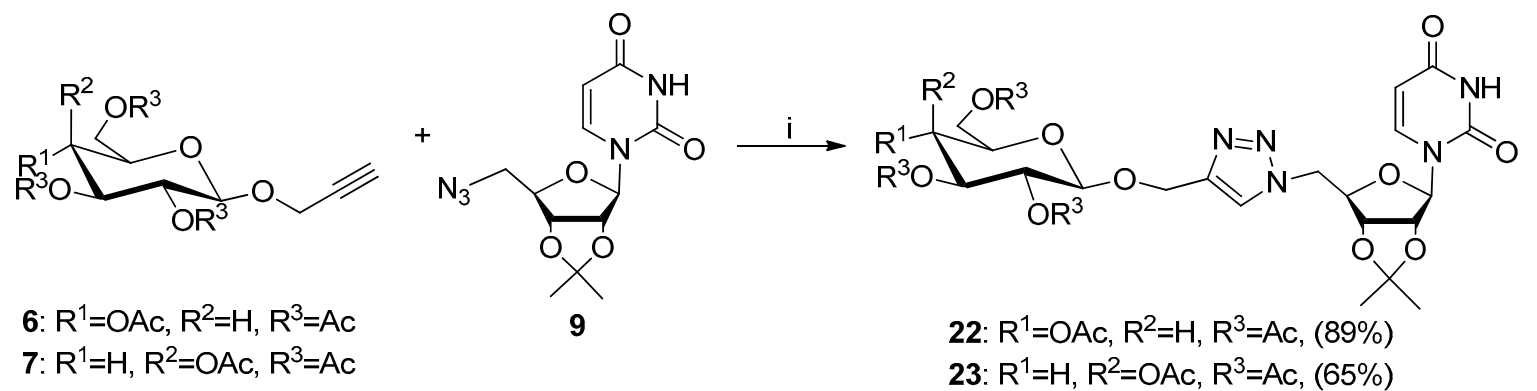

Scheme 6. Synthesis of glycoconjugates type IV. Reagents and Conditions: (i) $\mathrm{CuSO}_{4} \cdot 5 \mathrm{H}_{2} \mathrm{O}, \mathrm{NaASC}$, $\mathrm{THF} / i-\mathrm{PrOH}, \mathrm{H}_{2} \mathrm{O}$, r.t.

All the carried out $\mathrm{CuAAC}$ reactions proceeded with good or very good yields and led to the formation of only derivatives containing 1,4-disubstituted 1,2,3-triazole. The structures of all glycoconjugates were confirmed by means of nuclear magnetic resonance (NMR) and high resolution mass spectroscopy (HRMS.)

\subsection{Biological Evaluation}

\subsubsection{Antiviral Activity of Uridine Glycoconjugates Against Tick-Borne Encephalitis Virus}

As the initial steps of the biological evaluation of synthesized compounds we performed cytotoxicity studies according to the established method [19]. Cytotoxicity was analyzed using MTS-based cell proliferation assay in the permissive for TBEV-A549 cell line. Cytotoxic concentration $\left(C_{50}\right)$ values for each compound were estimated in order to choose non-toxic doses for further antiviral activity studies. $\mathrm{CC}_{50}$ values for the compounds 13-23 were 129, 114, 153, 136, 137, 69, 77, 184, 116, 173 and $157 \mu \mathrm{M}$, respectively. All of the uridine glycoconjugates showed dose-dependent cytotoxic 
effects with relatively moderate level of toxicity; below a concentration of $25 \mu \mathrm{M}$ all of the compounds did not significantly influence the viability of the cells.

Preliminary screening of antiviral effects of eleven tested compounds was performed using two TBEV strains (Hypr and Neudoerfl) by assessing cytopathic effect (CPE) inhibition assay and plaque reduction assay as previously reported [19]. The compounds were tested at the non-toxic concentration of $25 \mu \mathrm{M}$. TBEV Hypr strain is a highly cytopathic virus causing A549 cell death $96 \mathrm{~h}$ post-infection. To analyze the antiviral activity of the tested compounds, their protective effect on cell survival was measured using a colorimetric assay. In A549-TBEV infected DMSO-treated cells the rate of cell death was about 50\% (Figure 2). In A549-TBEV, infected cells treated with $25 \mu \mathrm{M}$ of compounds 18, 19, 20 and 21, the rate of cell death was significantly decreased. Two compounds (20 and 21) were the most active from the series. TBEV-induced CPE effect was nearly completely inhibited after treatment with $25 \mu \mathrm{M}$ of both compounds. The cell death was also strongly reduced after treatment with two other compounds (18 and 19). The inhibition of cell death was not observed for other tested compounds. A strong CPE was still observed in A549 cells treated with these compounds, indicating that these compounds have almost no antiviral activity against TBEV.

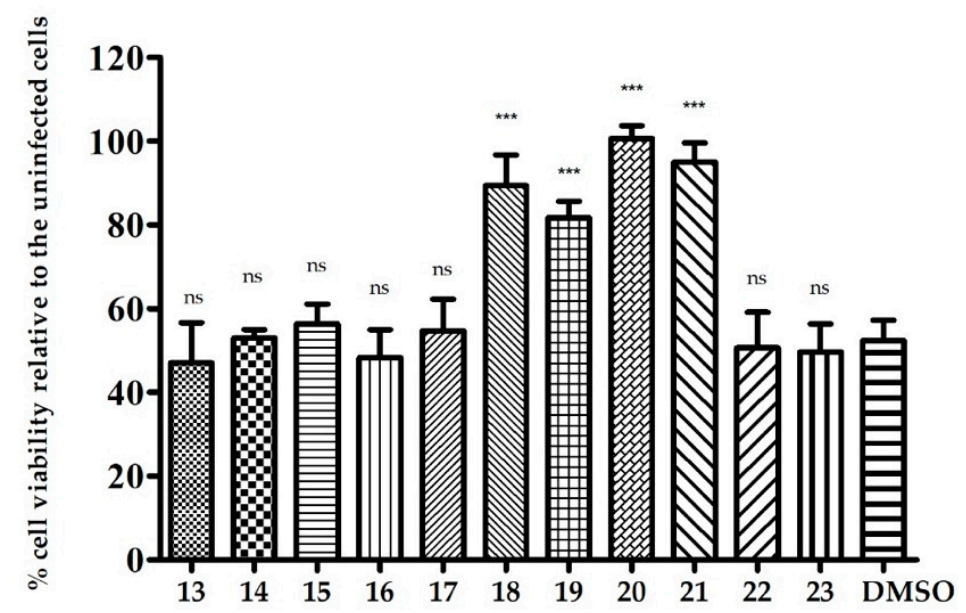

Figure 2. The effect of uridine glycoconjugates on tick-borne encephalitis virus (TBEV)-induced cytopathic effect. A549-infected cells (TBEV Hypr strain (multiplicity of infection (MOI) of 0.1)) were treated with $25 \mu \mathrm{M}$ of tested compounds or DMSO. After $48 \mathrm{~h}$, the cell death was measured and calculated as the percentage of the cell viability. Error bars represent standard deviations from 3 separate experiments. ns: not significant; ${ }^{* *}: p<0.001$ compared to infected DMSO-treated cells by one-way ANOVA with Dunnett's post-test.

These results were further confirmed using plaque reduction assay where the dose of $25 \mu \mathrm{M}$ of all synthesized compounds was tested for the inhibition of TBEV propagation in A549 cells using the immunoperoxidase monolayer assay (IPMA). A low multiplicity of infection (0.001) of low cytopathic Neudoerfl strain was used to detect the single areas of infected cells by the immunostaining of E protein. The infected DMSO-treated cells were used as positive control. Viral plaques were counted and expressed as percentage in comparison to the number of plaques detected in the positive control set as $100 \%$. As shown in Figure 3 compounds 18, 19, 20 and 21 effectively inhibited virus propagation in comparison to infected DMSO-treated cells. The reduction in size and number of plaques after $48 \mathrm{~h}$ compounds treatment was observed. As in previous experiment compounds 20 and $\mathbf{2 1}$ were the most active causing nearly a complete inhibition of TBEV propagation. Treatment with compounds 13-17 and 22-23 had no effect on TBEV infection; therefore, these compounds were not used in further analysis. 


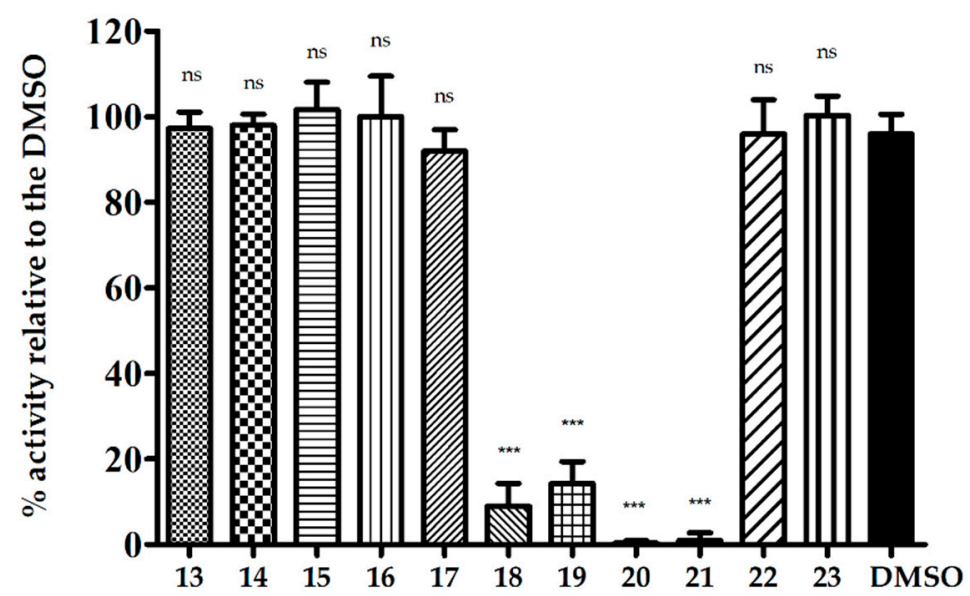

Figure 3. The effect of uridine glycoconjugates on TBEV infection in A549 cells. A549 cells were infected with the TBEV Neudoerfl strain at an MOI of 0.001. At $2 \mathrm{~h}$ post-infection (p.i.) the virus was removed, cells were washed and overlaid with carboxymethylcellulose in Dulbecco's Modified Eagle's Medium with DMSO or various doses of tested compounds. At $48 \mathrm{~h}$ p.i., cells were fixed, and infected foci were visualized by immunostaining with the monoclonal anti-Flavivirus group antigen antibody (4G2). Viral plaques were counted and expressed as percentage in comparison to the number of plaques detected in DMSO-treated infected cells set as 100\%. Error bars represent standard deviations from 3 separate experiments. ns: not significant; ${ }^{* * *}: p<0.001$ compared to infected DMSO-treated cells by one-way ANOVA with Dunnett's post-test.

\subsubsection{Dose-Response Activity of Uridine Glycoconjugates Against Tick-Borne Encephalitis Virus}

Four compounds that showed strong TBEV antiviral activity in the initial experiments were further evaluated to determine the dose-response inhibitory effect. Neudoerfl TBEV-infected monolayers of A549 cells (multiplicity of infection $(\mathrm{MOI})=0.001$ ) were incubated with increasing concentrations of the most active compounds: 18, 19, 20, $21(0-25 \mu \mathrm{M})$ diluted in the overlay medium for $48 \mathrm{~h}$ and the plaque reduction assay described above was performed. Plaques were immunostained and counted. All four tested compounds showed a dose-dependent reduction in the number of positive infected foci (Figure 4). Compounds 20 and 21 were the most active because the highest inhibition of plaque formation was observed in the case of all tested doses of these compounds. At the dose of $25 \mu \mathrm{M}$ no plaques were detected. The dose of $12.5 \mu \mathrm{M}$ of both compounds significantly reduced the number of plaques by $96 \%$ and $92 \%$, respectively, when compared to infected DMSO-treated cells. Moreover, the dose of $6.25 \mu \mathrm{M}$ caused $75 \%$ and $62 \%$ reductions in the number of plaques for compounds 20 and 21 , respectively. For less active compounds 18 and 19, the decrease in the number of plaques at the highest doses of 25 and $12.5 \mu \mathrm{M}$ was also observed. An amount of $25 \mu \mathrm{M}$ of both compounds reduced the number of plaques by $98 \%$ and $81 \%$, respectively.

Next, compounds 18-21 have been tested for their effect on the infectious virus titers in a dose-response assay. A549 cells were infected with low MOI of the virus (0.001, Neudoerfl strain) and treated with 0-25 $\mu \mathrm{M}$ concentrations of compounds. The culture supernatants collected $72 \mathrm{~h}$ p.i. were used to determine the viral titers using the plaque assay. The results were used to determine half-maximal inhibitory concentration $\left(\mathrm{IC}_{50}\right)$ values and to calculate selectivity index $(\mathrm{SI})$ values $\left(\mathrm{CC}_{50} / \mathrm{IC}_{50}\right.$ ratio) shown in Table 1.

The titer for the positive control (TBEV collected from non-treated cells) was $1 \times 10^{7}$ plaque-forming unit $/ \mathrm{mL}(\mathrm{PFU} / \mathrm{mL})$. Four tested compounds $(\mathbf{1 8}, 19,20$ and 21) significantly reduced TBEV titers in a dose-dependent manner confirming their anti-TBEV activity (Figure 5). Compounds 20 and 21 were the most active. After treatment with $25 \mu \mathrm{M}$ of both compounds and $12.5 \mu \mathrm{M}$ of compound 20 no virus was detected. Treatment with $6.25 \mu \mathrm{M}$ of compound 20 and $12.5 \mu \mathrm{M}$ of compound 21 caused $10^{3}-10^{4}$-fold reduction in viral titer, respectively. Compounds 18 and 19 caused nearly $10^{3}-10^{6}$-fold reduction in viral titer after treatment with 25 and $12.5 \mu \mathrm{M}$. The highest $\mathrm{IC}_{50}$ value $-3.7 \mu \mathrm{M}$ was obtained for compound $\mathbf{2 0}$ and due to its low cytotoxicity it reached a high SI of 49.7. 


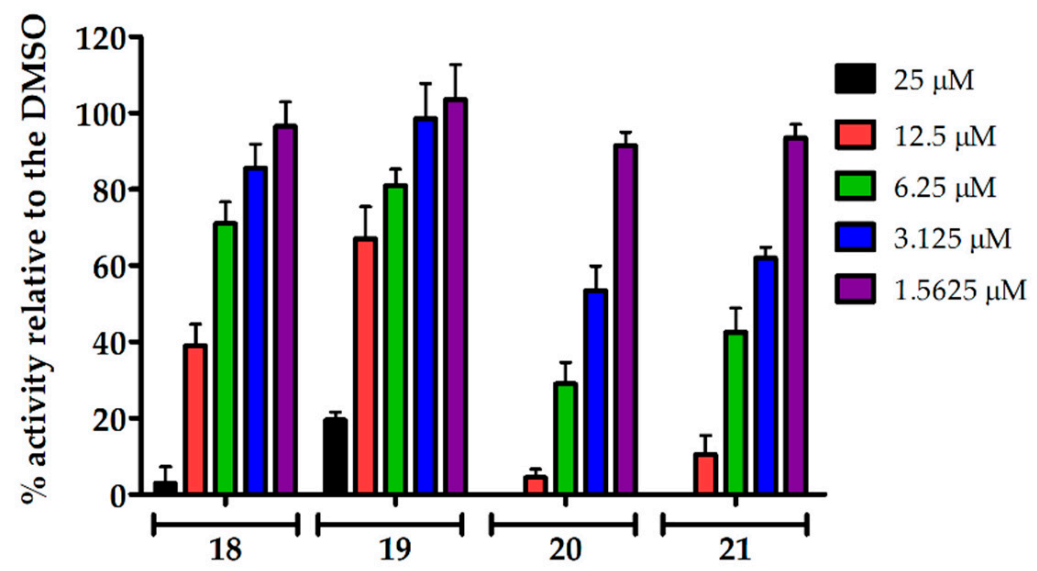

Figure 4. The effect of uridine glycoconjugates on TBEV infection in A549 cells. A549 cells were infected with the TBEV Neudoerfl strain at an MOI of 0.001. At $2 \mathrm{~h}$ p.i. the virus was removed, cells were washed and overlaid with carboxymethylcellulose in Dulbecco's Modified Eagle's Medium with DMSO or various doses of tested compounds $(0-25 \mu \mathrm{M})$. At $48 \mathrm{~h}$ p.i., cells were fixed, and infected foci were visualized by immunostaining with the monoclonal anti-Flavivirus group antigen antibody (4G2). Viral plaques were counted and expressed as percentage in comparison to the number of plaques detected in DMSO-treated infected cells set as $100 \%$. Error bars represent standard deviations from 3 separate experiments.

Table 1. Antiviral activity of uridine glycoconjugates 18-21 against TBEV Neudoerfl strain.

\begin{tabular}{cccccc}
\hline Type of Uridine Glycoconjugate Structure & Compound & $\mathbf{C C}_{\mathbf{5 0}}(\boldsymbol{\mu M})^{\mathbf{a}}$ & $\mathbf{I C}_{\mathbf{5 0}}(\boldsymbol{\mu M})^{\mathbf{b}}$ & $\mathbf{S I}^{\mathbf{c}}$ \\
\hline \multirow{2}{*}{ II } & $\mathbf{1 8}$ & 69 & 9.3 & 7.4 \\
\cline { 2 - 5 } & $\mathbf{1 9}$ & 77 & 15.1 & 5.1 \\
\hline \multirow{2}{*}{ III } & $\mathbf{2 0}$ & 184 & 3.7 & 49.7 \\
\cline { 2 - 5 } & $\mathbf{2 1}$ & 116 & 4.7 & 24.7 \\
\hline
\end{tabular}

a Concentration of the compound causing reduction in cell viability by $50 \%$; ${ }^{\mathrm{b}}$ Concentration to reduce infectious viral titers by $50 \%$; ${ }^{\mathrm{c}}$ Selectivity index (SI): $\mathrm{CC}_{50} / \mathrm{IC}_{50}$.

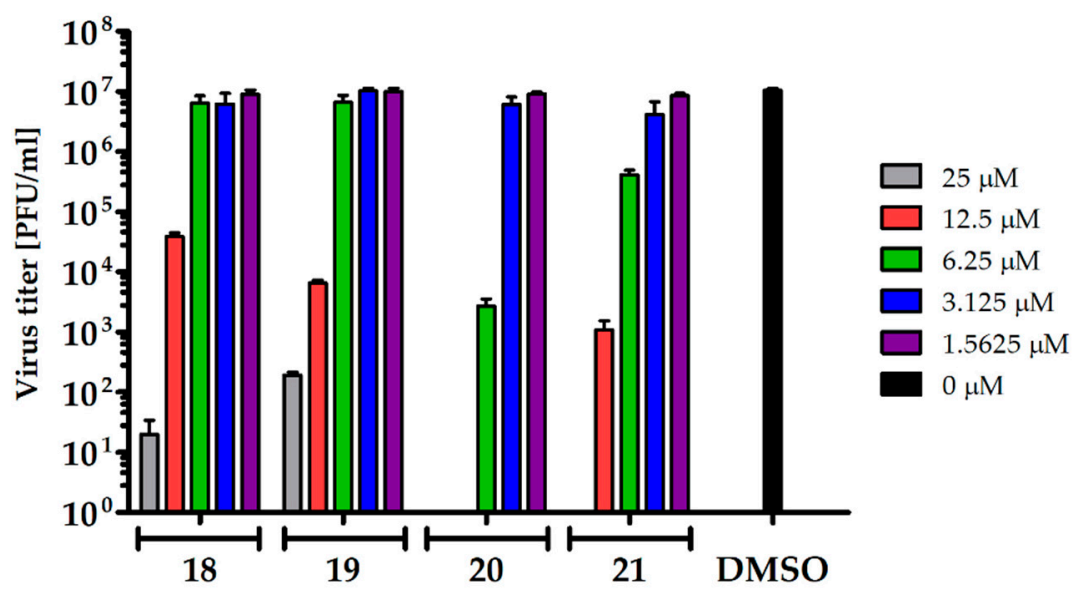

Figure 5. The effect of uridine glycoconjugates 18, 19, 20 and 21 on TBEV titers. A549 cells were infected with the TBEV Neudoerfl strain at an MOI of 0.1 and treated with various doses of tested compounds $(0-25 \mu \mathrm{M})$. At $72 \mathrm{~h}$ p.i., culture supernatants were collected to determine TBEV titers by plaque assay. Error bars represent standard deviations from 3 separate experiments. 


\subsubsection{The Activity of Uridine Glycoconjugates on Protein Synthesis}

Previously, we reported that the synthesis of viral glycoproteins of CSFV and influenza virus is impaired after treatment with uridine derivatives $[36,37]$. The uridine glycoconjugates described in this report were also designed to target glycosyltransferases, therefore we assessed the influence of tested compounds on TBEV glycoprotein production using Western blot analysis of TBEV Neudoerfl strain infected and treated cells lysates. A dose-dependent reduction in the production of E protein was observed after treatment with compounds 18, 19 and 21. The representative results for compound 21 are shown in Figure 6. To our surprise, all tested doses of compound $20(25-1.5625 \mu \mathrm{M})$ caused the complete inhibition of viral protein synthesis as E protein was not detected in Western blot analysis (Figure 6). After treatment with each of tested compounds, the non-glycosylated and under-glycosylated form of E protein were not detected probably due to their degradation.

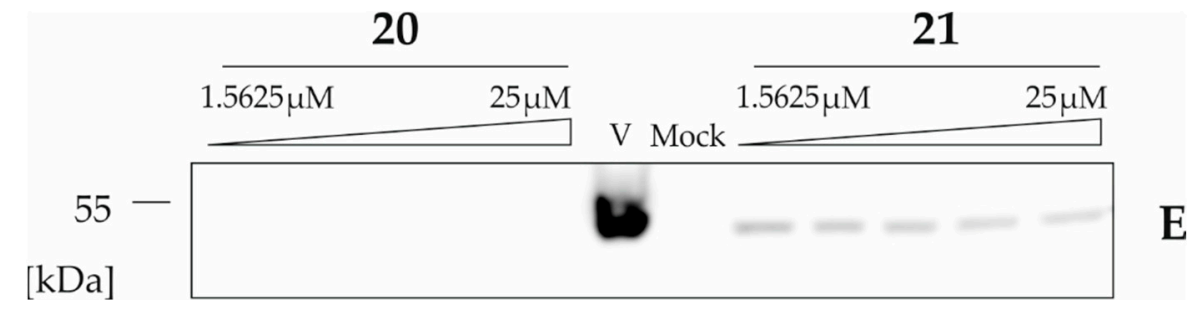

Figure 6. Analysis of TBEV E glycoprotein synthesis after treatment with uridine glycoconjugates. A549 cells were infected with TBEV Neudoerfl strain, MOI of 0,1. At $2 \mathrm{~h}$ p.i., cells were treated with various doses of compound 20, 21 or DMSO diluted in the medium for $48 \mathrm{~h}$. Cell lysates were prepared and separated by SDS-PAGE (gradient $10-20 \%$ polyacrylamide). The E protein was detected in Western blot analysis using monoclonal anti-Flavivirus group antigen antibody (4G2).

\section{Discussion}

Due to the continuous changes of the global climate, which influences the geographical distribution of ticks and mosquitoes, flaviviruses are an expanding threat to the human population. New endemic centers and outbreaks of emerging and re-emerging flaviviruses are often reported. Although, vaccines against some flaviviruses are commercially available e.g., anti-TBEV and anti-YFV, vaccination is not mandatory, or it is not $100 \%$ effective. Moreover, in spite of much effort put in the development of the effective antiviral therapy against flaviviruses, no drugs were approved for clinical use. Tick-borne encephalitis virus causing the most important and serious neurological infections is one of the most pathogenic flaviviruses constituting a public health problem in Europe and Asia. Several thousand cases of TBE are registered annually, however due to the large number of asymptomatic infections the scale is much wider.

$\mathrm{N}$-glycans attached to flavivirus proteins play multiple roles in the replication cycle including attachment to the host cell, assembly and secretion of virions. Glycosylated E protein of flaviviruses may interact with cell surface lectins during the attachment step. The interaction of C-type lectin dendritic cell-specific intercellular adhesion molecule-3-grabbing nonintegrin (DC-SIGN) and DC-SIGN-related protein (DC-SIGNR) with E glycoprotein of many flaviviruses: ZIKV, WNV, DENV and Japanese encephalitis virus (JEV) was reported [38-42]. The interaction with DC-SIGN and DC-SIGNR depends on the virus, presence of the glycan as well as on the complexity of the glycan chain. However, these type of lectins are expressed only on the macrophages and dendritic cells (DCs) or on microvascular endothelial cells [43]. Another study showed that glycosylation of ZIKV E protein plays a role during attachment to other cell types like A549 cell line, but is dispensable for infection in Vero cells [44]. Both cell lines lack DC-SIGN or DC-SIGNR, which may suggest that other lectins may be involved in the attachment of virus to some cell types. Moreover, glycosylation of both flavivirus envelope proteins prM and E could be also a crucial factor for proper folding, assembly and egress through the secretory pathway, although involvement of glycans in these processes has not been fully understood. The ablation of the $N$-glycosylation site in the prM or E protein of TBEV, ZIKV or WNV influences the expression and 
secretion of virus-like particles or subviral particles [45-47]. These reports suggest that glycan chains may stabilize formation of $\mathrm{E}$ protein dimers or may interact with some chaperone-like proteins during the transport of virions through the secretory compartments. For TBEV it has been shown that inhibition of $\mathrm{N}$-glycosylation of E protein or glucose trimming of the carbohydrate side chain of this protein results in the decrease in VLPs secretion, suggesting the role of $N$-glycans in assembly and/or secretion step [48]. In another study, it has been proven that the glycan associated with TBEV E-154 glycosylation site plays an important role in the secretion of VLPs from mammalian cells, however the glycosylation of the prM protein plays a less important role in this process [45]. Moreover, the impairment of TBEV E protein glycosylation did not affect the total level of secreted E protein in mammalian cells, however the conformation structure of the protein was affected resulting in the reduction in infectivity of secreted virions also in a mice model. In contrast, the deletion of the glycosylation site of E protein did not affect TBEV growth in tick cells [17]. The significant difference in the carbohydrate profile of TBEV E protein when grown in human and tick cells can be the explanation of this phenomenon [49]. As glycosylation plays highly crucial, yet multifaceted roles during the flavivirus replication cycle, we anticipate that targeting of this process may be a promising approach to antiviral therapy.

As the first step of our research, we evaluated the antiviral activity of 11 novel uridine glycoconjugates containing amide or/and 1,2,3-triazole moiety in the linker structure against TBEV, a member of the Flavivirus genus. At the initial screening, four compounds $(18,19,20,21)$ at the non-toxic dose $(25 \mu \mathrm{M})$ significantly increased cell survival after infection of A549 cells with a pathogenic strain of TBEV (Hypr strain) (Figure 2). The antiviral activity of all glycoconjugates was further evaluated in the virus plaque formation assay, using a low pathogenic strain of TBEV (Neudoerfl strain) (Figure 3). Again, only these four compounds showed strong antiviral activity at the same dose, reducing the formation of viral plaques. Compounds 18 and 19 belong to the type II glycoconjugates, while compounds 20 and 21 to type III (Figure 1). It is worth noting that both active types of glycoconjugates contain a 1,2,3-triazole ring in the linker structure which results from the $\mathrm{CuAAC}$ reaction of glycosyl azides with propargyl derivatives of uridine. The presence of TBDMS groups in the uridine fragment turned out to be significant factor for the activity. This is evidenced by the significantly lower activity of glycoconjugates $\mathbf{1 6}$ and $\mathbf{1 7}$ containing isopropylidene protection in the uridine fragment, which represent the analogues of active compounds 18 and 19. The presence of an amide moiety in glycoconjugates $\mathbf{1 8}$ and $\mathbf{1 9}$ also significantly affects the cytotoxicity of these compounds, which translates into a reduced selectivity index. When the amide bond in the uridine fragment was replaced with a linkage by an oxygen atom (compounds 20 and 21), the cytotoxicity of the glycoconjugates thus obtained decreased two-fold, while their activity increased significantly. On the other hand, the type of sugar unit present in the glycoconjugates has a little effect on the observed activity and cytotoxicity.

Dose-dependent studies of the influence of four the most active compounds were performed using a plaque reduction assay (Figure 4). Moreover, the dose-dependent activity on TBEV titer reduction were used for the estimation of $\mathrm{IC}_{50}$ values (Figure 5, Table 1). Compound $\mathbf{2 0}$ showed the most potent antiviral activity, reaching $3.7 \mu \mathrm{M}$ as IC $\mathrm{I}_{50}$ value, which resulted in the highest SI of 49,7 . The $\mathrm{IC}_{50}$ value of compound 21 was also high $-4.7 \mu \mathrm{M}$. Two other compounds (18 and 19) demonstrated moderate level of TBEV propagation inhibition ( $\mathrm{IC}_{50}=9.3$ and $15.1 \mu \mathrm{M}$, respectively). Our observations are similar to previously published data, that the lack of $\mathrm{N}$-glycosylation site in the E protein of TBEV reduces virion secretion out of mammalian cells [17].

To further characterize the activity of tested compounds, we investigated their influence on the production of E protein using Western blot analysis, as tested compounds were designed to inhibit the activity of $\beta$-1,4-galactosyltransferase I during the late steps of $N$-glycosylation process. The production of E protein was affected by compounds studied by us in a dose-dependent manner. The production of viral proteins was greatly decreased at all tested concentrations as shown for the representative compound 21 (Figure 6). For the most active compound 20, the complete inhibition of viral protein synthesis was observed at all tested doses of this compound. It is worthwhile to note that neither less glycosylated nor 
non-glycosylated forms of E protein were detected probably due to the quick degradation process of non-matured forms. The reduction in the glycoprotein E production after inhibitory treatment can be the reason for the decrease in TBEV viral production observed in previous experiments.

Summarizing, the four tested compounds $(18,19,20$ and 21) showed significant antiviral activity against two strains of tick-borne encephalitis virus. On the basis of these results, we conclude that compounds targeting $\mathrm{N}$-glycosylation process of viral proteins may constitute a new promising approach in antiviral strategy.

\section{Materials and Methods}

\subsection{General Information}

Nuclear magnetic resonance $\left({ }^{1} \mathrm{H}-\mathrm{NMR}\right.$ and $\left.{ }^{13} \mathrm{C}-\mathrm{NMR}\right)$ spectra were determined in $\mathrm{CDCl}_{3}$ or DMSO-d6 using tetramethyl silane (TMS) as an internal standard and recorded with an Agilent spectrometer at a frequency of $400 \mathrm{MHz}$ or with a Varian spectrometer at a frequency of $600 \mathrm{MHz}$. NMR solvents were purchased from ACROS Organics (Geel, Belgium). Chemical shifts ( $\delta$ ) are given in parts per million (ppm) and coupling constants $(J)$ are given in Hz. Splitting patterns are designated as follows: $\mathrm{s}$, singlet; $\mathrm{d}$, doublet; $\mathrm{dd}$, doublet of doublets; $\mathrm{t}$, triplet; $\mathrm{dd} \sim \mathrm{t}$, doublet of doublets resembling a triplet; $\mathrm{ddd}$, doublet of doublet of doublets; $\mathrm{m}$, multiplet; bs, broad singlet. Optical rotations were measured with a JASCO P-2000 polarimeter using a sodium lamp $(589.3 \mathrm{~nm})$ at room temperature. Melting point measurements were performed on OptiMelt (MPA 100) Stanford Research Systems. Mass spectra were recorded with a WATERS LCT Premier XE LC/MS system (high-resolution mass spectrometer equipped with an electron spray ionization source and a high-resolution orthogonal TOF analyzer). Reactions were monitored by Thin-Layer Chromatography (TLC) on precoated plates of silica gel 60 F254 (Merck KGaA, Darmstadt, Germany). TLC plates were inspected under UV light $(\lambda=254 \mathrm{~nm})$ or charring after spraying with $10 \%$ sulfuric acid in ethanol. Products were purified using column chromatography performed on Silica Gel 60 (70-230 mesh, Merck KGaA, Darmstadt, Germany) developed with toluene/EtOAc or $\mathrm{CHCl}_{3} / \mathrm{MeOH}$ solvent systems in various volume ratios. All evaporations were performed on a rotary evaporator under reduced pressure at $45^{\circ} \mathrm{C}$.

2,3,4,6-Tetra-O-acetyl- $\beta$-D-glucopyranosyl azide (1), 2,3,4,6-tetra-O-acetyl- $\beta$-D-galactopyranosyl azide (2) [23], 2,3,4,6-tetra-O-acetyl- $\beta$-D-glucopyranosyl amine (3), 2,3,4,6-tetra- $O$-acetyl- $\beta$ D-galactopyranosyl amine (4), 2,3,4,6-tetra-O-benzyl- $\beta$-D-galactopyranosyl amine (5) [31], propargyl 2,3,4,6-tetra-O-acetyl- $\beta$-D-glucopyranoside (6), propargyl 2,3,4,6-tetra-O-acetyl- $\beta$ D-galactopyranoside (7) [32], 2', $3^{\prime}$-O-isopropylidene-uridine-5'-carboxylic acid (8) [50], $5^{\prime}$-azido-5'-deoxy-2', $3^{\prime}$-O-isopropylidene-uridine (9) [51], $\mathrm{N}$-propargyl-2', $3^{\prime}$-O-isopropylideneuridine5'-amide (10) [24], 2',3'-di-O-tert-butyldimethylsilyl-uridine-5'-carboxylic acid (11a) [18], $2^{\prime}, 3^{\prime}$-di-O-tert-butyldimethylsilyl-uridine (12a) [52] as well as glycoconjugates (13, 14, 16 and 17) [29] were prepared according to the respective published procedures. Sugars, uridine and other used chemicals were purchased from Sigma-Aldrich (Steinheim, Germany), ACROS Organics (Geel, Belgium) or Avantor (Gliwice, Poland) and were used without purification.

\subsection{Chemistry}

\subsubsection{Procedure for Synthesis of N-Propargyl-2',, $3^{\prime}$-O-Tert-Butyldimethylsilyluridine-5'-Amide $\mathbf{1 1}$}

$2^{\prime}, 3^{\prime}$-Di-O-tert-butyldimethylsilyl-uridine-5'-carboxylic acid 11a (224 mg, $\left.0.46 \mathrm{mmol}\right)$ was dissolved in dichloromethane $(6 \mathrm{~mL})$ followed by addition of DCC ( $96 \mathrm{mg}, 0.46 \mathrm{mmol}$ ) and propargyl amine $(32 \mu \mathrm{L}, 0.50 \mathrm{mmol})$ and mixed for $24 \mathrm{~h}$ at r.t. The reaction progress was monitored on TLC in an eluents system toluene:ethyl acetate (1:1). After the reaction was completed, the reaction mixture was concentrated under diminished pressure and the crude product was purified by column chromatography (toluene:ethyl acetate; gradient: 10:1 to 6:1) to give $\mathbf{1 1}(180 \mathrm{mg}, 75 \%)$ as a colorless oil. 
N-propargyl-2', $3^{\prime}$-di-O-tert-butyldimethylsilyl-uridine-5'-amide(11): $[\alpha]_{D}^{25}=-27.7\left(\mathrm{c}=2.4, \mathrm{CHCl}_{3}\right)$, ${ }^{1} \mathrm{H}-\mathrm{NMR}\left(\mathrm{CDCl}_{3}, 400 \mathrm{MHz}\right) \delta:-0.02,0.04,0.12,0.18\left(4 \mathrm{~s}, 12 \mathrm{H}, \mathrm{CH}_{3} \mathrm{Si}\right), 0.85,0.93\left(2 \mathrm{~s}, 6 \mathrm{H},\left(\mathrm{CH}_{3}\right)_{3} \mathrm{C}\right)$, $2.23\left(\mathrm{dd} \sim \mathrm{t}, 1 \mathrm{H}, J=2.4 \mathrm{~Hz}, J=2.4 \mathrm{~Hz}, \mathrm{CH}_{2} \mathrm{CC} \underline{\mathrm{H}}\right), 4.02-4.15\left(\mathrm{~m}, 2 \mathrm{H}, \underline{\mathrm{C}}_{2} \mathrm{CCH}\right), 4.26(\mathrm{dd}, 1 \mathrm{H}, J=1.2 \mathrm{~Hz}$, $\left.J=4.3 \mathrm{~Hz}, \mathrm{H}-3^{\prime}\right), 4.39\left(\mathrm{~d}, 1 \mathrm{H}, J=1.2 \mathrm{~Hz}, \mathrm{H}-4^{\prime}\right), 4.68\left(\mathrm{dd}, 1 \mathrm{H}, J=4.3 \mathrm{~Hz}, J=7.2 \mathrm{~Hz}, \mathrm{H}-2^{\prime}\right), 5.39(\mathrm{~d}, 1 \mathrm{H}$, $\left.J=7.2 \mathrm{~Hz}, \mathrm{H}-1^{\prime}\right), 5.78(\mathrm{~d}, 1 \mathrm{H}, J=8.0 \mathrm{~Hz}, \mathrm{H}-5 \mathrm{ur}), 7.44(\mathrm{~d}, 1 \mathrm{H}, J=8.0 \mathrm{~Hz}, \mathrm{H}-6 \mathrm{ur}), 7.77(\mathrm{t}, 1 \mathrm{H}, J=5.1 \mathrm{~Hz}$, $\left.\mathrm{NHCH}_{2}\right) .{ }^{13} \mathrm{C}-\mathrm{NMR}\left(\mathrm{CDCl}_{3}, 100 \mathrm{MHz}\right) \delta:-5.13,-4.74,-4.61\left(\mathrm{CH}_{3} \mathrm{Si}\right), 17.85,17.99\left(\left(\mathrm{CH}_{3}\right)_{3} \underline{\mathrm{C}}\right), 25.67$, $25.76\left(\left(\mathrm{CH}_{3}\right)_{3} \mathrm{C}\right), 28.80\left(\mathrm{NHCH}_{2} \mathrm{CCH}\right), 70.65,71.44,74.73\left(\mathrm{NHCH}_{2} \mathrm{CCH}, \mathrm{C}-2^{\prime}, \mathrm{C}-3^{\prime}\right), 79.03\left(\mathrm{NHCH}_{2} \underline{\mathrm{CCH}}\right)$,

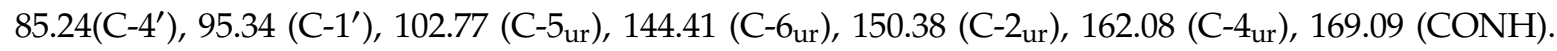
ESI-HRMS: calcd for $\mathrm{C}_{24} \mathrm{H}_{41} \mathrm{~N}_{3} \mathrm{O}_{6} \mathrm{Si}_{2} \mathrm{Na}[\mathrm{M}+\mathrm{Na}]^{+}: m / z 546.2432$. Found: $m / z$ 546.2435.

\subsubsection{Procedure for Synthesis Of $2^{\prime}, 3^{\prime}$-Di-O-Tert-Butyldimethylsilyl-5'-O-Propargyl-Uridine $\mathbf{1 2}$}

$2^{\prime}, 3^{\prime}$-Di-O-tert-butyldimethylsilyluridine 12a (482 mg, $\left.1.03 \mathrm{mmol}\right)$ was dissolved in THF (10 mL) followed by addition of sodium hydride $(130 \mathrm{mg}, 5.42 \mathrm{mmol})$. The flask with the reaction mixture was placed in an ice bath and stirred for $30 \mathrm{~min}$. Next propargyl bromide $(102 \mu \mathrm{L}, 1.18 \mathrm{mmol})$ was added and the whole mixture was placed in an ultrasonic bath for $4 \mathrm{~h}$. The reaction progress was monitored on TLC in an eluents system toluene:ethyl acetate (1:1). After the reaction was completed, methanol $(1 \mathrm{~mL})$ and water $(5 \mathrm{~mL})$ were added to the reaction mixture. The product was extracted with ethyl acetate $(3 \times 10 \mathrm{~mL})$. The combined organic phases were dried over anhydrous $\mathrm{MgSO}_{4}$, filtered and concentrated under reduced pressure. The crude product was purified by column chromatography (toluene:ethyl acetate; gradient: 20:1 to 8:1) to give $\mathbf{1 2}$ (309 $\mathrm{mg}, 59 \%)$ as a white solid.

$2^{\prime}, 3^{\prime}$-Di-O-tert-butyldimethylsilyl-5'-O-propargyl-uridine $(\mathbf{1 2}):[\alpha]_{D}^{25}=37.6\left(\mathrm{c}=1.0, \mathrm{CHCl}_{3}\right)$, m.p. $=66-68{ }^{\circ} \mathrm{C},{ }^{1} \mathrm{H}-\mathrm{NMR}\left(\mathrm{CDCl}_{3}, 400 \mathrm{MHz}\right) \delta: 0.08,0.09,0.12,0.13\left(4 \mathrm{~s}, 12 \mathrm{H}, \mathrm{CH}_{3} \mathrm{Si}\right), 0.90,0.91$ $\left(2 \mathrm{~s}, 18 \mathrm{H},\left(\mathrm{CH}_{3}\right)_{3} \mathrm{C}\right), 2.49\left(\mathrm{dd} \sim \mathrm{t}, 1 \mathrm{H}, J=2.4 \mathrm{~Hz}, J=2.4 \mathrm{~Hz}, \mathrm{CH}_{2} \mathrm{CC} \underline{\mathrm{H}}\right), 3.68(\mathrm{dd}, 1 \mathrm{H}, J=2.0 \mathrm{~Hz}$, $\left.J=10.6 \mathrm{~Hz}, \mathrm{H}-5^{\prime} \mathrm{b}\right), 3.87\left(\mathrm{dd}, 1 \mathrm{H}, J=2.2 \mathrm{~Hz}, J=10.6 \mathrm{~Hz}, \mathrm{H}-5^{\prime} \mathrm{a}\right), 4.08-4.18\left(\mathrm{~m}, 3 \mathrm{H}, \mathrm{H}-2^{\prime}, \mathrm{H}-3^{\prime}, \mathrm{H}-4^{\prime}\right)$, $3.96-4.27\left(\mathrm{~m}, 2 \mathrm{H}, \mathrm{CH}_{2} \mathrm{CCH}\right), 4.16\left(\mathrm{ddd}, 1 \mathrm{H}, J=2.6 \mathrm{~Hz}, J=6.3 \mathrm{~Hz}, J=17.6 \mathrm{~Hz}, \mathrm{NHCH}_{2} \mathrm{CCH}\right)$, $5.70\left(\mathrm{dd}, 1 \mathrm{H}, J=2.2 \mathrm{~Hz}, J=8.0 \mathrm{~Hz}, \mathrm{H}-5_{\mathrm{ur}}\right), 5.79\left(\mathrm{~d}, 1 \mathrm{H}, J=3.1 \mathrm{~Hz}, \mathrm{H}-1^{\prime}\right), 8.00(\mathrm{~d}, 1 \mathrm{H}, J=8.2 \mathrm{~Hz}$, $\mathrm{H}-6$ ur $), 8.62(\mathrm{~s}, 1 \mathrm{H}, \mathrm{NH}) .{ }^{13} \mathrm{C}-\mathrm{NMR}\left(\mathrm{CDCl}_{3}, 100 \mathrm{MHz}\right) \delta:-5.01,-4.86,-4.57,-4.30\left(\mathrm{CH}_{3} \mathrm{Si}\right), 18.01$, $18.07\left(\left(\mathrm{CH}_{3}\right)_{3} \underline{\mathrm{C}}\right), 25.79,25.83\left(\left(\mathrm{CH}_{3}\right)_{3} \mathrm{C}\right), 58.58\left(\mathrm{OCH}_{2} \mathrm{CCH}\right), 67.96\left(\mathrm{C}-5^{\prime}\right), 70.70,75.15,75.91\left(\mathrm{C}-2^{\prime}, \mathrm{C}-3^{\prime}\right.$, $\left.\mathrm{CH}_{2} \mathrm{CCH}\right), 78.68\left(\mathrm{CH}_{2} \underline{\mathrm{CCH}}\right), 82.59$ (C-4'), 89.60 (C-1)', 101.69 (C-5 ur), 140.48 (C-6ur), $150.19\left(\mathrm{C}-2_{\text {ur }}\right)$, 163.20 (C-4 $4_{\text {ur }}$ ). ESI-HRMS: calcd for $\mathrm{C}_{24} \mathrm{H}_{42} \mathrm{~N}_{2} \mathrm{O}_{6} \mathrm{Si}_{2} \mathrm{Na}[\mathrm{M}+\mathrm{Na}]^{+}: \mathrm{m} / z$ 533.2479. Found: $m / z$ 533.2478.

\subsubsection{General Procedure for Synthesis of Glycoconjugates 13-15 By Amide Bond Formation}

$2^{\prime}, 3^{\prime}$-O-Isopropylidene-uridine-5'-carboxylic acid 8 ( $\left.86 \mathrm{mg}, 0.29 \mathrm{mmol}\right)$ was dissolved in $\mathrm{MeOH}$ ( $3 \mathrm{~mL}$ ) followed by addition of acetylated glycosyl amine 3 or $4(100 \mathrm{mg}, 0.29 \mathrm{mmol})$ or benzylated glycosyl amine 5 (156 mg, $0.29 \mathrm{mmol}$ ) and mixed for $5 \mathrm{~min}$ at r.t. Then, 2-chloro-4,6-dimethoxy-1,3,5triazine ( $56 \mathrm{mg}, 0.32 \mathrm{mmol}$ ) and 4-methylmorpholine $(35 \mu \mathrm{L}, 0.32 \mathrm{mmol}$ ) were added and the reaction was continued for $5 \mathrm{~h}$ at r.t. The reaction mixture was concentrated under reduced pressure, dissolved in $\mathrm{CH}_{2} \mathrm{Cl}_{2}(30 \mathrm{~mL})$ and washed with brine $(5 \mathrm{~mL})$, saturated $\mathrm{NaHCO}_{3}(5 \mathrm{~mL})$ and once again with brine $(5 \mathrm{~mL})$. The organic layer was dried over anhydrous $\mathrm{MgSO}_{4}$ and concentrated under reduced pressure. Crude products were purified by column chromatography (chloroform:methanol; gradient: 100:1 to 75:1 in case of products $\mathbf{1 3}$ and $\mathbf{1 4}$ or toluene:ethyl acetate; gradient 4:1 to 2:1 in case of product 15) to give $\mathbf{1 3}(144 \mathrm{mg}, 80 \%)$ or $\mathbf{1 4}(155 \mathrm{mg}, 86 \%)$ or $\mathbf{1 5}(100 \mathrm{mg}, 42 \%)$ as white solids.

$N$-(2", 3", 4", 6"-tetra-O-benzyl- $\beta$-D-galactopyranosyl)-2', 3'-O-isopropylidene-uridine-5'-amide

(Glycoconjugate 15): $[\alpha]_{D}^{20}=-17.3\left(\mathrm{c}=1.0, \mathrm{CHCl}_{3}\right),{ }^{1} \mathrm{H}-\mathrm{NMR}\left(\mathrm{CDCl}_{3}, 400 \mathrm{MHz}\right) \delta: 1.21,1.53(2 \mathrm{~s}, 6 \mathrm{H}$, $\left.\left(\mathrm{CH}_{3}\right)_{2} \mathrm{C}\right), 3.52-3.59\left(\mathrm{~m}, 2 \mathrm{H}, \mathrm{H}-6 \mathrm{a}_{\text {gal }}, \mathrm{H}-6 \mathrm{~b}_{\text {gal }}\right), 3.68(\mathrm{dd}, 1 \mathrm{H}, J=2.4 \mathrm{~Hz}, J=9.4 \mathrm{~Hz}, \mathrm{H}-3$ gal $), 3.69(\mathrm{~m}, 1 \mathrm{H}$, $\left.\mathrm{H}-5_{\mathrm{gal}}\right), 3.82\left(\mathrm{dd} \sim \mathrm{t}, 1 \mathrm{H}, J=9.0 \mathrm{~Hz}, J=9.4 \mathrm{~Hz}, \mathrm{H}-2_{\text {gal }}\right), 3.99\left(\mathrm{~d}, 1 \mathrm{H}, J=2.4 \mathrm{~Hz}, \mathrm{H}-4_{\text {gal }}\right), 4.40$ and 4.45 $\left(\mathrm{qAB}, 2 \mathrm{H}, J=12.0 \mathrm{~Hz}, \mathrm{C}_{2} \mathrm{Ph}\right), 4.43\left(\mathrm{~d}, 1 \mathrm{H}, J=3.2 \mathrm{~Hz}, \mathrm{H}-4^{\prime}\right), 4.59$ and $4.91(\mathrm{qAB}, 2 \mathrm{H}, J=11.3 \mathrm{~Hz}$, $\left.\mathrm{C}_{2} \mathrm{Ph}\right), 4.66$ and $4.73\left(\mathrm{qAB}, 2 \mathrm{H}, J=11.6 \mathrm{~Hz}, \mathrm{C}_{2} \mathrm{Ph}\right), 4.75$ and $4.92\left(\mathrm{qAB}, 2 \mathrm{H}, J=11.7 \mathrm{~Hz}, \underline{\mathrm{C}}_{2} \mathrm{Ph}\right)$, $4.77\left(\mathrm{dd}, 1 \mathrm{H}, J=3.1 \mathrm{~Hz}, J=6.6 \mathrm{~Hz}, \mathrm{H}-2^{\prime}\right), 4.82\left(\mathrm{dd}, 1 \mathrm{H}, J=3.2 \mathrm{~Hz}, J=6.6 \mathrm{~Hz}, \mathrm{H}-3^{\prime}\right), 5.20(\mathrm{dd} \sim \mathrm{t}, 1 \mathrm{H}$, $\left.J=9.0 \mathrm{~Hz}, J=9.4 \mathrm{~Hz}, \mathrm{H}-1_{\mathrm{gal}}\right), 5.43\left(\mathrm{dd}, 1 \mathrm{H}, J=3.1 \mathrm{~Hz}, \mathrm{H}-1^{\prime}\right), 5.62(\mathrm{dd}, 1 \mathrm{H}, J=1.9 \mathrm{~Hz}, J=7.8 \mathrm{~Hz}$, 
H-5 $\mathrm{ur}_{\text {r }}, 7.09$ (d, $\left.1 \mathrm{H}, J=7.8 \mathrm{~Hz}, \mathrm{H}-6_{\text {ur }}\right), 7.20$ (d, 1H, $\left.J=9.4 \mathrm{~Hz}, \mathrm{NH}_{\text {amide }}\right), 7.23-7.38$ (m, 20H, H-Ph), 8.22 (bs, 1H, NH). ${ }^{13} \mathrm{C}-\mathrm{NMR}\left(\mathrm{CDCl}_{3}, 100 \mathrm{MHz}\right) \delta: 27.14,25.02\left(\left(\mathrm{CH}_{3}\right)_{2} \mathrm{C}\right), 68.10\left(\mathrm{C}-6_{\mathrm{gal}}\right), 72.54,73.45$, 73.46, $74.16\left(\underline{\mathrm{CH}}_{2} \mathrm{Ph}\right), 74.80,75.01\left(\mathrm{C}-4_{\text {gal }}, \mathrm{C}-5_{\mathrm{gal}}\right), 78.04\left(\mathrm{C}-3^{\prime}\right), 78.98,82.07\left(\mathrm{C}-2_{\mathrm{gal}}, \mathrm{C}-3_{\mathrm{gal}}\right), 82.67$ (C-2' $), 83.29$ (C-1 gal $), 85.31$ (C-4'), 96. 86 (C-1'), 102.91 (C-5 ur $\left.^{\prime}\right), 127.13,127.41,127.47,127.63,127.73$, 127.76, 127.81, 127.86, 127.94, 127.99, 128.22, 128.28, 128.3, 128.35, 128.41, 128.44, 137.73, 138.01, 138.40, 138.78 (C-Ph), 142.78, 149.81 (C-6ur, C-2 ur $), 162.20$ (C-4 ur $), 169,08$ (CONH).ESI-HRMS: calcd for $\mathrm{C}_{46} \mathrm{H}_{49} \mathrm{~N}_{3} \mathrm{O}_{11} \mathrm{Na}[\mathrm{M}+\mathrm{Na}]^{+}: \mathrm{m} / z$ 842.3265. Found: $m / z$ 842.3268.

\subsubsection{General Procedure for Synthesis of Glycoconjugates $16-23$ by CuAAC Reaction}

Procedure A: To a solution of $O$-acetylated glycosyl azides 5 or $6(86 \mathrm{mg}, 0.23 \mathrm{mmol})$ and $\mathrm{N}$-propargyl-2', $3^{\prime}$-O-isopropylidene-uridine-5'-amide 10 (77 $\left.\mathrm{mg}, 0.23 \mathrm{mmol}\right)$ or $\mathrm{N}$-propargyl2',3'-di-O-tert-butyldimethylsilyl-uridine-5'-amide $11(120 \mathrm{mg}, 0.23 \mathrm{mmol})$ or 2',3'-di-O-tertbutyldimethylsilyl-5'-O-propargyl-uridine $12(117 \mathrm{mg}, 0.23 \mathrm{mmol})$ in THF $(2 \mathrm{~mL})$ and $i$-PrOH $(2 \mathrm{~mL})$ mixture, $\mathrm{CuSO}_{4} \cdot 5 \mathrm{H}_{2} \mathrm{O}(12 \mathrm{mg}, 0.046 \mathrm{mmol})$ dissolved in $\mathrm{H}_{2} \mathrm{O}(1 \mathrm{~mL})$ was added followed by addition of sodium ascorbate $(18 \mathrm{mg}, 0.09 \mathrm{mmol})$ dissolved in $\mathrm{H}_{2} \mathrm{O}(1 \mathrm{~mL})$. The reaction mixture was stirred for $5 \mathrm{~h}$ (during synthesis of products 16 and 17) or for $24 \mathrm{~h}$ at r.t. (synthesis of products 18-23). Mixture was concentrated in vacuo and purified by column chromatography to give products 16-23.

1-(2",3", 4", 6"-tetra-O-acetyl- $\beta$-D-glucopyranosyl)-4-(2', 3'-di-O-tert-butyldimethylsilyl-uridine-5'carbonylaminomethyl)-[1,2,3]-triazole (Glycoconjugate 18): The crude product was purified by column chromatography (toluene:ethyl acetate; gradient: 6:1 to 1:1) to give $\mathbf{1 8}(142 \mathrm{mg}, 69 \%)$ as a white solid. $[\alpha]_{D}^{25}=-32.6\left(\mathrm{c}=1.0, \mathrm{CHCl}_{3}\right), \mathrm{m} . \mathrm{p} .=117-120{ }^{\circ} \mathrm{C},{ }^{1} \mathrm{H}-\mathrm{NMR}\left(\mathrm{CDCl}_{3}, 400 \mathrm{MHz}\right) \delta:-0.04,0.04,0.13,0.19$ $\left(4 \mathrm{~s}, 12 \mathrm{H}, \mathrm{CH}_{3} \mathrm{Si}\right), 0.84,0.94\left(2 \mathrm{~s}, 18 \mathrm{H},\left(\mathrm{CH}_{3}\right)_{3} \mathrm{C}\right), 1.90,2.04,2.07,2.09\left(4 \mathrm{~s}, 12 \mathrm{H}, \mathrm{CH}_{3} \mathrm{CO}\right), 4.01$ (ddd, $1 \mathrm{H}$, $\left.J=2.0 \mathrm{~Hz}, J=4.4 \mathrm{~Hz}, J=9.8 \mathrm{~Hz}, \mathrm{H}-5_{\mathrm{glu}}\right), 4.17\left(\mathrm{dd}, 1 \mathrm{H}, J=2.0 \mathrm{~Hz}, J=12.6 \mathrm{~Hz}, \mathrm{H}-6 \mathrm{a}_{\mathrm{glu}}\right), 4.31-4.36$ $\left(\mathrm{m}, 2 \mathrm{H}, \mathrm{H}-6 \mathrm{~b}_{\text {glu }}, \mathrm{H}-3^{\prime}\right), 4.42\left(\mathrm{~s}, 1 \mathrm{H}, \mathrm{H}-4^{\prime}\right), 4.52-4.70\left(\mathrm{~m}, 2 \mathrm{H}, \mathrm{CH}_{2}\right), 4.71(\mathrm{dd}, 1 \mathrm{H}, J=4.3 \mathrm{~Hz}, J=7.8 \mathrm{~Hz}$, H-2' $), 5.23\left(\mathrm{~m}, 1 \mathrm{H}, \mathrm{H}-4_{\text {glu }}\right), 5.37-5.45$ (m, 3H, H-1' $\left., \mathrm{H}-2_{\text {glu }}, \mathrm{H}-3_{\text {glu }}\right), 5.77$ (dd, $1 \mathrm{H}, J=2.0 \mathrm{~Hz}, J=8.0 \mathrm{~Hz}$, $\left.\mathrm{H}-5_{\text {ur }}\right), 5.88\left(\mathrm{~m}, 1 \mathrm{H}, \mathrm{H}-1_{\text {glu }}\right), 7.41\left(\mathrm{~d}, 1 \mathrm{H}, J=8.0 \mathrm{~Hz}, \mathrm{H}-6_{\text {ur }}\right), 7.78\left(\mathrm{~s}, 1 \mathrm{H}, \mathrm{H}-5_{\text {triaz }}\right), 8.08(\mathrm{t}, 1 \mathrm{H}, J=5.1$ $\left.\mathrm{Hz}, \mathrm{NHCH}_{2}\right), 9.05(\mathrm{~s}, 1 \mathrm{H}, \mathrm{NH}) .{ }^{13} \mathrm{C}-\mathrm{NMR}\left(\mathrm{CDCl}_{3}, 100 \mathrm{MHz}\right) \delta:-5.17,-4.74,-4.71,-4.55\left(\mathrm{CH}_{3} \mathrm{Si}\right)$, $17.83,17.98\left(\left(\mathrm{CH}_{3}\right)_{3} \underline{\mathrm{C}}\right), 20.24,20.48,20.50,20.65\left(\mathrm{CH}_{3} \mathrm{CO}\right), 25.66,25.76\left(\left(\underline{\mathrm{CH}}_{3}\right)_{3} \mathrm{C}\right), 34.99\left(\mathrm{NHCH}_{2}\right)$, $61.42\left(\mathrm{C}-6_{\text {glu }}\right), 67.61,70.59,70.61,72.70,74.76,75.19\left(\mathrm{C}-4_{\text {glu }}, \mathrm{C}-3_{\text {glu }}, \mathrm{C}-2_{\text {glu }}, \mathrm{C}-5_{\text {glu }}, \mathrm{C}-2^{\prime}, \mathrm{C}-3^{\prime}\right), \overline{85.56}$, $85.73\left(\mathrm{C}-4^{\prime}, \mathrm{C}-1_{\text {glu }}\right), 95.02\left(\mathrm{C}-1^{\prime}\right), 102.89$ (C-5 ur $), 120.11$ (C-5 triaz. $\left._{\text {. }}\right), 144.28,145.04$ (C-6 $\left.6_{\text {ur }}, \mathrm{C}-4_{\text {triaz. }}\right), 150.48$ $\left(\mathrm{C}-2_{\mathrm{ur}}\right), 162.50\left(\mathrm{C}-4_{\mathrm{ur}}\right), 169.30,169.36,169.94,170.52(\mathrm{CO})$. ESI-LRMS: calcd for $[\mathrm{M}+\mathrm{Na}]^{+}: \mathrm{m} / \mathrm{z}$ 919.3553. Found: $m / z$ 919.3560.

1-(2",3",4", 6"-tetra-O-acetyl- $\beta$-D-galactopyranosyl)-4-(2',3'-di-O-tert-butyldimethylsilyl-uridine-5'carbonylaminomethyl)-[1,2,3]-triazole (Glycoconjugate 19): The crude product was purified by column chromatography (toluene:ethyl acetate; gradient: 8:1 to 1:1) to give 19 (148 $\mathrm{mg}, 72 \%)$ as a white solid. $[\alpha]_{D}^{25}=-16.4\left(\mathrm{c}=1.0, \mathrm{CHCl}_{3}\right)$, m.p. $=126-128{ }^{\circ} \mathrm{C},{ }^{1} \mathrm{H}-\mathrm{NMR}\left(\mathrm{CDCl}_{3}, 400 \mathrm{MHz}\right) \delta:-0.05,0.04,0.13$, $0.20\left(4 \mathrm{~s}, 12 \mathrm{H}, \mathrm{CH}_{3} \mathrm{Si}\right), 0.84,0.94\left(2 \mathrm{~s}, 18 \mathrm{H},\left(\mathrm{CH}_{3}\right)_{3} \mathrm{C}\right), 1.91,2.02,2.05,2.22\left(4 \mathrm{~s}, 12 \mathrm{H}, \mathrm{CH}_{3} \mathrm{CO}\right), 4.16-4.26$ $\left(\mathrm{m}, 3 \mathrm{H}, \mathrm{H}-5_{\text {gal }}, \mathrm{H}-6 \mathrm{a}_{\text {gal }}, \mathrm{H}-6 \mathrm{~b}_{\text {gal }}\right), 4.31\left(\mathrm{dd}, 1 \mathrm{H}, J=0.8 \mathrm{~Hz}, J=4.3 \mathrm{~Hz}, \mathrm{H}-3^{\prime}\right), 4.42(\mathrm{~d}, 1 \mathrm{H}, J=0.8 \mathrm{~Hz}$, $\left.\mathrm{H}-4^{\prime}\right), 4.52(\mathrm{~m}, 1 \mathrm{H}, \mathrm{CH}), 4.66-4.74\left(\mathrm{~m}, 2 \mathrm{H}, \mathrm{CH}, \mathrm{H}-2^{\prime}\right), 5.24\left(\mathrm{dd}, 1 \mathrm{H}, J=3.5 \mathrm{~Hz}, J=10.0 \mathrm{~Hz}, \mathrm{H}-3_{\text {gal }}\right)$, $5.42\left(\mathrm{~d}, 1 \mathrm{H}, J=7.8 \mathrm{~Hz}, \mathrm{H}-1^{\prime}\right), 5.53\left(\mathrm{dd} \sim \mathrm{t}, 1 \mathrm{H}, J=9.4 \mathrm{~Hz}, J=10.0 \mathrm{~Hz}, \mathrm{H}-2_{\text {gal }}\right), 5.55(\mathrm{~d}, 1 \mathrm{H}, J=3.5 \mathrm{~Hz}$, $\left.\mathrm{H}-4_{\text {gal }}\right), 5.76\left(\mathrm{dd}, 1 \mathrm{H}, J=2.3 \mathrm{~Hz}, J=8.0 \mathrm{~Hz}, \mathrm{H}-5_{\mathrm{ur}}\right), 5.84\left(\mathrm{~d}, 1 \mathrm{H}, J=9.4 \mathrm{~Hz}, \mathrm{H}-1_{\text {gal }}\right), 7.42(\mathrm{~d}, 1 \mathrm{H}$, $\left.J=8.0 \mathrm{~Hz}, \mathrm{H}-6_{\mathrm{ur}}\right), 7.83\left(\mathrm{~s}, 1 \mathrm{H}, \mathrm{H}-5_{\text {triaz }}\right), 8.04\left(\mathrm{t}, 1 \mathrm{H}, J=5.3 \mathrm{~Hz}, \mathrm{NHCH}_{2}\right), 8.85(\mathrm{~s}, 1 \mathrm{H}, \mathrm{NH}) .{ }^{13} \mathrm{C}-\mathrm{NMR}$ $\left(\mathrm{CDCl}_{3}, 100 \mathrm{MHz}\right) \delta:-5.14,-4.69,-4.67,-4.51\left(\mathrm{CH}_{3} \mathrm{Si}\right), 17.87,18.04\left(\left(\mathrm{CH}_{3}\right)_{3} \mathrm{C}\right), 20.37,20.50,20.63$, $20.65\left(\underline{\mathrm{CH}}_{3} \mathrm{CO}\right), 25.69,25.80\left(\left(\mathrm{CH}_{3}\right)_{3} \mathrm{C}\right), 35.00\left(\mathrm{NHCH}_{2}\right), 61.21\left(\mathrm{C}-6_{\text {gal }}\right), 66.88\left(\mathrm{C}-4_{\text {gal }}\right), 68.16\left(\mathrm{C}-3^{\prime}\right), 70.69$ $\left(\mathrm{C}-3_{\mathrm{gal}}\right), 70.85\left(\mathrm{C}-2_{\mathrm{gal}}\right), 74.21\left(\mathrm{C}-5_{\mathrm{gal}}\right), 74.81\left(\mathrm{C}-2^{\prime}\right), 85.62,86.30$ (C-4', C-1 $\left.1_{\mathrm{gal}}\right), 94.98\left(\mathrm{C}-1^{\prime}\right), 102.87$ (C-5 $\left.5_{\mathrm{ur}}\right)$, 120.32 (C-5 triaz. $\left._{\text {. }}\right), 144.26,144.75$ (C-6 ur $\left._{\text {, C- }} 4_{\text {triaz. }}\right), 150.42$ (C-2 $\left.2_{\text {ur }}\right), 162.38$ (C-4 $\left.4_{\text {ur }}\right), 169.36,169.55,169.94$, 170.36 (CO). ESI-LRMS: calcd for $[\mathrm{M}+\mathrm{Na}]^{+}: \mathrm{m} / z$ 919.3553. Found: $m / z 919.3563$.

1-(2",3", 4", 6"-tetra-O-acetyl- $\beta$-D-glucopyranosyl)-4-(2', $3^{\prime}$-di-O-tert-butyldimethylsilyl-uridine-5'-Omethyl)-[1,2,3]-triazole (Glycoconjugate 20): The crude product was purified by column chromatography (toluene:ethyl acetate; gradient: 6:1 to $2: 1)$ to give $\mathbf{2 0}(146 \mathrm{mg}, 72 \%)$ as a white solid. $[\alpha]_{D}^{25}=4.0(\mathrm{c}=1.0$, 
$\left.\mathrm{CHCl}_{3}\right)$, m.p. $=105-108{ }^{\circ} \mathrm{C},{ }^{1} \mathrm{H}-\mathrm{NMR}\left(\mathrm{CDCl}_{3}, 400 \mathrm{MHz}\right) \delta:-0.01,0.06,0.07,0.08\left(4 \mathrm{~s}, 12 \mathrm{H}, \mathrm{CH}_{3} \mathrm{Si}\right), 0.88$, $0.90\left(2 \mathrm{~s}, 18 \mathrm{H},\left(\mathrm{CH}_{3}\right)_{3} \mathrm{C}\right), 1.87,2.03,2.04,2.07\left(4 \mathrm{~s}, 12 \mathrm{H}, \mathrm{CH}_{3} \mathrm{CO}\right), 3.68(\mathrm{dd}, 1 \mathrm{H}, J=1.4 \mathrm{~Hz}, J=10.6 \mathrm{~Hz}$, H-5' a), 4.03 (ddd, $\left.1 \mathrm{H}, J=1.8 \mathrm{~Hz}, J=4.9 \mathrm{~Hz}, J=10.1 \mathrm{~Hz}, \mathrm{H}-5_{\mathrm{glu}}\right), 4.09-4.15\left(\mathrm{~m}, 3 \mathrm{H}, \mathrm{H}-2^{\prime}, \mathrm{H}-3^{\prime}, \mathrm{H}-4^{\prime}\right)$, $4.18\left(\mathrm{dd}, 1 \mathrm{H}, J=1.8 \mathrm{~Hz}, J=12.7 \mathrm{~Hz}, \mathrm{H}-6 \mathrm{a}_{\mathrm{glu}}\right), 4.35\left(\mathrm{dd}, 1 \mathrm{H}, J=4.9 \mathrm{~Hz}, J=12.7 \mathrm{~Hz}, \mathrm{H}-6 \mathrm{~b}_{\mathrm{glu}}\right), 4.64$ and $4.72\left(\mathrm{qAB}, 2 \mathrm{H}, J=11.9 \mathrm{~Hz}, \mathrm{CH}_{2}\right), 5.25\left(\mathrm{dd} \sim \mathrm{t}, 1 \mathrm{H}, J=9.4 \mathrm{~Hz}, J=10.1 \mathrm{~Hz}, \mathrm{H}-4_{\text {glu }}\right), 5.38(\mathrm{dd} \sim \mathrm{t}, 1 \mathrm{H}$, $\left.J=9.0 \mathrm{~Hz}, J=9.8 \mathrm{~Hz}, \mathrm{H}-2_{\text {glu }}\right), 5.43\left(\mathrm{dd} \sim \mathrm{t}, 1 \mathrm{H}, J=9.4 \mathrm{~Hz}, J=9.8 \mathrm{~Hz}, \mathrm{H}-3_{\text {glu }}\right), 5.65(\mathrm{dd}, 1 \mathrm{H}, J=1.8 \mathrm{~Hz}$, $\left.J=8.2 \mathrm{~Hz}, \mathrm{H}-5_{\mathrm{ur}}\right), 5.78\left(\mathrm{~d}, 1 \mathrm{H}, J=3.1 \mathrm{~Hz}, \mathrm{H}-1^{\prime}\right), 5.89\left(\mathrm{~d}, 1 \mathrm{H}, J=9.0 \mathrm{~Hz}, \mathrm{H}-1_{\text {glu }}\right), 7.75\left(\mathrm{~s}, 1 \mathrm{H}, \mathrm{H}-5_{\text {triaz }}\right)$, 7.94 (s, 1H, NH), 7.95 (d, 1H, J = $8.2 \mathrm{~Hz}, \mathrm{H}-6 \mathrm{ur}) .{ }^{13} \mathrm{C}-\mathrm{NMR}\left(\mathrm{CDCl}_{3}, 100 \mathrm{MHz}\right) \delta:-4.98,-4.82,-4.62$, -4.32 $\left(\mathrm{CH}_{3} \mathrm{Si}\right), 18.01,18.10\left(\left(\mathrm{CH}_{3}\right)_{3} \underline{\mathrm{C}}\right), 20.13,20.50,20.54,20.68\left(\mathrm{C}_{3} \mathrm{CO}\right), 25.80,25.84\left(\left(\mathrm{CH}_{3}\right)_{3} \mathrm{C}\right)$, $61.54\left(\mathrm{C}-6_{\text {glu }}\right), 64.32\left(\mathrm{CH}_{2}\right), 67.75\left(\mathrm{C}-5^{\prime}\right), 68.60,70.39\left(\mathrm{C}-3_{\text {glu }}, \mathrm{C}-4_{\text {glu }}\right), 70.94,72.51,75.41,75.84\left(\mathrm{C}-2_{\text {glu }}\right.$, C-5 glu, C-2', C-3'), 82.83, 85.91 (C-4', C-1 $\left.1_{\text {glu }}\right), 89.46$ (C-1'), 101.86 (C-5 ur $\left.^{\prime}\right), 120.60$ (C-5 $\left.5_{\text {triaz. }}\right), 140.75$, 144.71 (C-6 ur $_{\text {, }}$ C-4 triaz. $\left._{\text {. }}\right), 150.11$ (C-2 ur $), 162.75$ (C-4 $\left.{ }_{\text {ur }}\right), 169.02,169.37,169.80,170.39$ (CO). ESI-LRMS: calcd for $[\mathrm{M}+\mathrm{Na}]^{+}: m / z$ 906.3600. Found: $m / z$ 906.3581.

1-(2",3", 4", 6"-tetra-O-acetyl- $\beta$-D-galactopyranosyl)-4-(2', 3'-di-O-tert-butyldimethylsilyl-uridine-5'-Omethyl)-[1,2,3]-triazole (Glycoconjugate 21): The crude product was purified by column chromatography (toluene:ethyl acetate; gradient: $6: 1$ to $2: 1)$ to give $21(150 \mathrm{mg}, 74 \%)$ as a white solid. $[\alpha]_{D}^{25}=17.2(\mathrm{c}=1.0$, $\left.\mathrm{CHCl}_{3}\right)$, m.p. $=104-107{ }^{\circ} \mathrm{C},{ }^{1} \mathrm{H}-\mathrm{NMR}\left(\mathrm{CDCl}_{3}, 400 \mathrm{MHz}\right) \delta: 0.05,0.06,0.07,0.08\left(4 \mathrm{~s}, 12 \mathrm{H}, \mathrm{CH}_{3} \mathrm{Si}\right), 0.88$, $0.90\left(2 \mathrm{~s}, 18 \mathrm{H},\left(\mathrm{CH}_{3}\right)_{3} \mathrm{C}\right), 1.88,2.02,2.04,2.21\left(4 \mathrm{~s}, 12 \mathrm{H}, \mathrm{CH}_{3} \mathrm{CO}\right), 3.68(\mathrm{dd}, 1 \mathrm{H}, J=2.2 \mathrm{~Hz}, J=10.8 \mathrm{~Hz}$, H-5' a), 3.88 (dd, 1H, J = 2.2 Hz, J = 10.8 Hz, H-5'b), 4.09-4.27 (m, 6H, H-5 gal, H-6a gal, H-6b gal, H-2', $\left.\mathrm{H}-3^{\prime}, \mathrm{H}-4^{\prime}\right), 4.65$ and $4.73\left(\mathrm{qAB}, 2 \mathrm{H}, J=11.9 \mathrm{~Hz}, \mathrm{CH}_{2}\right), 5.27\left(\mathrm{dd}, 1 \mathrm{H}, J=3.5 \mathrm{~Hz}, J=10.2 \mathrm{~Hz}, \mathrm{H}-3_{\text {gal }}\right)$, $5.50\left(\mathrm{dd} \sim \mathrm{t}, 1 \mathrm{H}, J=9.4 \mathrm{~Hz}, J=10.2 \mathrm{~Hz}, \mathrm{H}-2_{\text {gal }}\right), 5.57\left(\mathrm{~d}, 1 \mathrm{H}, J=3.5 \mathrm{~Hz}, \mathrm{H}-4_{\text {gal }}\right), 5.66(\mathrm{dd}, 1 \mathrm{H}, J=2.4 \mathrm{~Hz}$, $\left.J=8.2 \mathrm{~Hz}, \mathrm{H}-5_{\mathrm{ur}}\right), 5.79\left(\mathrm{~d}, 1 \mathrm{H}, J=3.1 \mathrm{~Hz}, \mathrm{H}-1^{\prime}\right), 5.86\left(\mathrm{~d}, 1 \mathrm{H}, J=9.4 \mathrm{~Hz}, \mathrm{H}-1_{\text {gal }}\right), 7.80\left(\mathrm{~s}, 1 \mathrm{H}, \mathrm{H}-5_{\text {triaz }}\right)$, $7.95\left(\mathrm{~d}, 1 \mathrm{H}, J=8.2 \mathrm{~Hz}, \mathrm{H}-6_{\text {ur }}\right), 8.27$ (s, $\left.1 \mathrm{H}, \mathrm{NH}\right) .{ }^{13} \mathrm{C}-\mathrm{NMR}\left(\mathrm{CDCl}_{3}, 100 \mathrm{MHz}\right) \delta:-4.84,-4.69,-4.47$, $-4.19\left(\mathrm{CH}_{3} \mathrm{Si}\right), 18.14,18.24\left(\left(\mathrm{CH}_{3}\right)_{3} \underline{\mathrm{C}}\right), 20.36,20.61,20.73,20.76\left(\underline{\mathrm{CH}}_{3} \mathrm{CO}\right), 25.93,25.98\left(\left(\underline{\mathrm{CH}}_{3}\right)_{3} \mathrm{C}\right)$, $61.14\left(\mathrm{C}-6_{\mathrm{gal}}\right), 64.51\left(\mathrm{CH}_{2}\right), 66.91,68.18,68.75,70.76,71.10,74.36,76.00$ (C-5', C-4gal, C-3 gal $, \mathrm{C}-3^{\prime}, \mathrm{C}-2_{\mathrm{gal}}$, C-5 gal $_{\text {gal }}$ C-2' $), 82.92,86.55$ (C-4', C-1 gal $), 89.54\left(\mathrm{C}-1^{\prime}\right), 101.99$ (C-5 $\left.5_{\text {ur }}\right), 120.85$ (C-5 $\left.5_{\text {triaz. }}\right), 140.84,144.78$ (C-6 ur, $\left.\mathrm{C}-4_{\text {triaz. }}\right), 150.32$ (C-2 ur $), 163.07$ (C-4 ur $), 169.36,169.88,170.03,170.44$ (CO). ESI-LRMS: calcd for $[\mathrm{M}+\mathrm{Na}]^{+}: m / z$ 906.3600. Found: $m / z$ 906.3604.

$2^{\prime}, 3^{\prime}$-O-isopropylidene-5'-deoxy-5'-[4-(2",3", 4", 6"-tetra-O-acetyl- $\beta$-D-glucopyranosyl-oxymethyl)-1,2-3triazol-1-ylluridine (Glycoconjugate 22): The crude product was purified by column chromatography (toluene:ethyl acetate; gradient: 15:1 to 2:1 and next chloroform:methanol; gradient 100:1 to 40:1) to give $22(142 \mathrm{mg}, 89 \%)$ as a white solid. $[\alpha]_{D}^{24}=7.3\left(\mathrm{c}=1.0, \mathrm{CHCl}_{3}\right)$, m.p. $=108-110{ }^{\circ} \mathrm{C}$, ${ }^{1} \mathrm{H}-\mathrm{NMR}\left(\mathrm{CDCl}_{3}, 400 \mathrm{MHz}\right) \delta:$ 1.33, $1.55\left(2 \mathrm{~s}, 6 \mathrm{H},\left(\mathrm{CH}_{3}\right)_{2} \mathrm{C}\right), 1.99,2.00,2.03,2.09\left(4 \mathrm{~s}, 12 \mathrm{H}, \mathrm{CH}_{3} \mathrm{CO}\right)$, $3.73\left(\mathrm{ddd}, 1 \mathrm{H}, J=2.3 \mathrm{~Hz}, J=4.9 \mathrm{~Hz}, J=9.8 \mathrm{~Hz}, \mathrm{H}-5_{\text {glu }}\right), 4.15\left(\mathrm{dd}, 1 \mathrm{H}, J=2.3 \mathrm{~Hz}, J=12.1 \mathrm{~Hz}, \mathrm{H}-6 \mathrm{a}_{\text {glu }}\right)$, $4.23\left(\mathrm{dd}, 1 \mathrm{H}, J=4.9 \mathrm{~Hz}, J=12.7 \mathrm{~Hz}, \mathrm{H}-6 \mathrm{~b}_{\mathrm{glu}}\right), 4.47\left(\mathrm{ddd}, 1 \mathrm{H}, J=4.7 \mathrm{~Hz}, J=6.6 \mathrm{~Hz}, J=6.8 \mathrm{~Hz}, \mathrm{H}-4^{\prime}\right)$, $4.67\left(\mathrm{~d}, 1 \mathrm{H}, J=8.2 \mathrm{~Hz}, \mathrm{H}-1_{\text {glu }}\right), 4.68\left(\mathrm{dd}, 1 \mathrm{H}, J=6.8 \mathrm{~Hz}, J=14.1 \mathrm{~Hz}, \mathrm{H}-5^{\prime} \mathrm{a}\right), 4.73(\mathrm{dd}, 1 \mathrm{H}, J=4.3 \mathrm{~Hz}$, $\left.J=14.1 \mathrm{~Hz}, \mathrm{H}-5^{\prime} \mathrm{b}\right), 4.81$ and $4.93\left(\mathrm{qAB}, 2 \mathrm{H}, J=12.5 \mathrm{~Hz}, \mathrm{CH}_{2}\right), 4.91\left(\mathrm{dd}, 1 \mathrm{H}, J=4.7 \mathrm{~Hz}, J=6.7 \mathrm{~Hz}, \mathrm{H}-3^{\prime}\right)$, $5.10\left(\mathrm{dd}, 1 \mathrm{H}, J=8.2 \mathrm{~Hz}, J=9.4 \mathrm{~Hz}, \mathrm{H}-2_{\text {glu }}\right), 5.17\left(\mathrm{dd}, 1 \mathrm{H}, J=2.0 \mathrm{~Hz}, J=6.7 \mathrm{~Hz}, \mathrm{H}-2^{\prime}\right), 5.19(\mathrm{dd} \sim \mathrm{t}, 1 \mathrm{H}$, $\left.J=9.4 \mathrm{~Hz}, J=9.8 \mathrm{~Hz}, \mathrm{H}-4_{\text {glu }}\right), 5.21\left(\mathrm{dd} \sim \mathrm{t}, 1 \mathrm{H}, J=9.4 \mathrm{~Hz}, J=9.4 \mathrm{~Hz}, \mathrm{H}-3_{\text {glu }}\right), 5.50(\mathrm{~d}, 1 \mathrm{H}, J=2.0 \mathrm{~Hz}$, H-1'), $5.75(\mathrm{dd}, 1 \mathrm{H}, J=2.3 \mathrm{~Hz}, J=7.8 \mathrm{~Hz}, \mathrm{H}-5 \mathrm{ur}), 7.08\left(\mathrm{~d}, 1 \mathrm{H}, J=7.8 \mathrm{~Hz}, \mathrm{H}-6_{\mathrm{ur}}\right), 7.56\left(\mathrm{~s}, 1 \mathrm{H}, \mathrm{H}-5_{\text {triaz }}\right)$, $\left.8.59(\mathrm{~s}, 1 \mathrm{H}, \mathrm{NH}) .{ }^{13} \mathrm{C}-\mathrm{NMR}\left(\mathrm{CDCl}_{3}, 100 \mathrm{MHz}\right) \delta: 20.62,20.70,20.77\left(\mathrm{CH}_{3} \mathrm{CO}\right), 25.28,27.13\left(\mathrm{C}_{3}\right)_{2} \mathrm{C}\right)$, $51.64\left(\mathrm{C}-5^{\prime}\right), 61.92,63.16\left(\mathrm{C}-6_{\text {glu }}, \mathrm{CH}_{2}\right), 68.42,71.28,71.97,72.67\left(\mathrm{C}-2_{\text {glu }}, \mathrm{C}-3_{\text {glu }}, \mathrm{C}-4_{\text {glu }}, \mathrm{C}-5_{\mathrm{glu}}\right), 81.54$, 84.03, 85.92 (C-2', C-3', C-4' $), 96.33$ (C-1'), $100.23\left(\mathrm{C}-1_{\text {glu }}\right), 103.01$ (C-5 ur $\left.), 114.96\left(\mathrm{CH}_{3}\right)_{2} \mathrm{C}\right), 124.29$ (C-5 triaz. $), 143.22,144.11$ (C-6 $\left.6_{\text {ur }}, C-4_{\text {triaz. }}\right), 149.75$ (C-2 ur $), 162.48$ (C-4 ur $), 169.56,170.24,170.74$ (CO). ESI-LRMS: calcd for $[\mathrm{M}+\mathrm{H}]^{+}: m / z$ 696.2364. Found: $m / z$ 696.2407.

$2^{\prime}, 3^{\prime}$-O-isopropylidene-5'-deoxy-5'-[4-(2",3", 4", 6"-tetra-O-acetyl- $\beta$-D-galactopyranosyl-oxymethyl)-1,2-3triazol-1-ylluridine (Glycoconjugate 23): The crude product was purified by column chromatography (toluene:ethyl acetate; gradient: 15:1 to 2:1 and next chloroform:methanol; gradient 100:1 to 40:1) to give $23(104 \mathrm{mg}, 65 \%)$ as a white solid. $[\alpha]_{D}^{24}=1.2\left(\mathrm{c}=1.0, \mathrm{CHCl}_{3}\right), \mathrm{m} . \mathrm{p} .=101-105{ }^{\circ} \mathrm{C},{ }^{1} \mathrm{H}-\mathrm{NMR}$ $\left(\mathrm{CDCl}_{3}, 400 \mathrm{MHz}\right) \delta: 1.34,1.55\left(2 \mathrm{~s}, 6 \mathrm{H},\left(\mathrm{CH}_{3}\right)_{2} \mathrm{C}\right), 1.98,2.00,2.06,2.15\left(4 \mathrm{~s}, 12 \mathrm{H}, \mathrm{CH}_{3} \mathrm{CO}\right), 3.95(\mathrm{ddd}, 1 \mathrm{H}$, 
$\left.J=1.0 \mathrm{~Hz}, J=6.5 \mathrm{~Hz}, J=6.8 \mathrm{~Hz}, \mathrm{H}-5_{\mathrm{gal}}\right), 4.13\left(\mathrm{dd}, 1 \mathrm{H}, J=6.5 \mathrm{~Hz}, J=11.2 \mathrm{~Hz}, \mathrm{H}-6 \mathrm{a}_{\mathrm{gal}}\right), 4.17(\mathrm{dd}, 1 \mathrm{H}$, $\left.J=6.8 \mathrm{~Hz}, J=11.2 \mathrm{~Hz}, \mathrm{H}-6 \mathrm{~b}_{\mathrm{gal}}\right), 4.46\left(\mathrm{~m}, 1 \mathrm{H}, \mathrm{H}-4^{\prime}\right), 4.65\left(\mathrm{~d}, 1 \mathrm{H}, J=8.2 \mathrm{~Hz}, \mathrm{H}-1_{\mathrm{gal}}\right), 4.80$ and $4.97(\mathrm{qAB}$, $\left.2 \mathrm{H}, J=12.5 \mathrm{~Hz}, \mathrm{CH}_{2}\right), 4.68-4.77\left(\mathrm{~m}, 2 \mathrm{H}, \mathrm{H}-5^{\prime} \mathrm{a}, \mathrm{H}-5^{\prime} \mathrm{b}\right), 4.87\left(\mathrm{dd}, 1 \mathrm{H}, J=4.7 \mathrm{~Hz}, J=6.8 \mathrm{~Hz}, \mathrm{H}-3^{\prime}\right)$, $5.02\left(\mathrm{dd}, 1 \mathrm{H}, J=3.5 \mathrm{~Hz}, J=10.2 \mathrm{~Hz}, \mathrm{H}-3_{\mathrm{gal}}\right), 5.06\left(\mathrm{dd}, 1 \mathrm{H}, J=2.0 \mathrm{~Hz}, J=6.8 \mathrm{~Hz}, \mathrm{H}-2^{\prime}\right), 5.21(\mathrm{dd}, 1 \mathrm{H}$, $\left.J=8.2 \mathrm{~Hz}, J=10.2 \mathrm{~Hz}, \mathrm{H}-2_{\text {gal }}\right), 5.90\left(\mathrm{dd}, 1 \mathrm{H}, J=1.0 \mathrm{~Hz}, J=3.5 \mathrm{~Hz}, \mathrm{H}-4_{\text {gal }}\right), 5.55(\mathrm{~d}, 1 \mathrm{H}, J=2.0 \mathrm{~Hz}$, $\left.\mathrm{H}-1^{\prime}\right), 5.79\left(\mathrm{dd}, 1 \mathrm{H}, J=2.0 \mathrm{~Hz}, J=7.8 \mathrm{~Hz}, \mathrm{H}-5_{\mathrm{ur}}\right), 7.11\left(\mathrm{~d}, 1 \mathrm{H}, J=7.8 \mathrm{~Hz}, \mathrm{H}-6_{\mathrm{ur}}\right), 7.58\left(\mathrm{~s}, 1 \mathrm{H}, \mathrm{H}-5_{\text {triaz }}\right)$, $9.20(\mathrm{~s}, 1 \mathrm{H}, \mathrm{NH}) .{ }^{13} \mathrm{C}-\mathrm{NMR}\left(\mathrm{CDCl}_{3}, 100 \mathrm{MHz}\right) \delta:$ 20.56, 20.64, 20.70, $20.80\left(\mathrm{CH}_{3} \mathrm{CO}\right), 25.24,27.10$ $\left.\left(\underline{\mathrm{CH}}_{3}\right)_{2} \mathrm{C}\right), 51.60\left(\mathrm{C}-5^{\prime}\right), 61.31,63.22\left(\mathrm{CH}_{2}, \mathrm{C}-6_{\mathrm{gal}}\right), 67.04,68.88,70.75,70.86\left(\mathrm{C}-2_{\mathrm{gal}}, \mathrm{C}-3_{\mathrm{gal}}, \mathrm{C}-4_{\mathrm{gal}}, \mathrm{C}-5_{\mathrm{gal}}\right)$, 81.39, 83.91, 85.74 (C-2', C-3', $\left.\left.\mathrm{C}-4^{\prime}\right), 95.86\left(\mathrm{C}-1^{\prime}\right), 100.82\left(\mathrm{C}-1_{\mathrm{gal}}\right), 103.05\left(\mathrm{C}-5_{\mathrm{ur}}\right), 115.00\left(\mathrm{CH}_{3}\right)_{2} \mathrm{C}\right), 124.34$ (C-5 triaz. $), 143.24,144.10$ (C-6 ur $_{1}$ C-4 $\left.4_{\text {triaz. }}\right), 150.01$ (C-2 ur $\left._{2}\right), 162.92\left(\mathrm{C}-4_{\text {ur }}\right), 169.73,170.11,170.29,170.49$ (CO). ESI-LRMS: calcd for $[\mathrm{M}+\mathrm{H}]^{+}: m / z$ 696.2364. Found: $m / z$ 696.2468.

\subsection{Biological Evaluation of Compounds Activity}

\subsubsection{Antiviral Compounds}

The synthesized compounds were dissolved in DMSO and stored at $-20^{\circ} \mathrm{C}$ until future use.

\subsubsection{Cells and Viruses}

The A549 cell line (adenocarcinomic human alveolar basal epithelial cells, ATCC ${ }^{\circledR}$ CCL-185 ${ }^{\mathrm{TM}}$ ) was cultured in Dulbecco's Modified Eagle's Medium (D-MEM) (Corning, New York, USA) supplemented with $8 \%$ heat-inactivated fetal bovine serum (FBS), $100 \mathrm{U} / \mathrm{mL}$ penicillin, and $100 \mathrm{~g} / \mathrm{mL}$ streptomycin at $37^{\circ} \mathrm{C}$ under $5 \% \mathrm{CO}_{2}$. The Neudoerfl TBEV strain, kindly provided by Dr. Karin Stiasny (Center for Virology, Medical University of Vienna, Vienna, Austria) and the Hypr TBEV strain, kindly provided by Dr. Daniel Růžek (Department of Virology, Veterinary Research Institute, Brno, Czech Republic) were cultured in A549 cells for 3-4 days. The plaque assay method was used to determine TBEV virus titers.

\subsubsection{Cell Viability Assay}

A549 cell viability and compound cytotoxicity were estimated by the CellTiter 96 AQueous non-radioactive cell proliferation assay (MTS) (Promega, Madison, WI, USA) according to the manufacturer's instructions. The cytotoxicity measurements were done in three replicates. The half-maximal cytotoxic concentration $\left(\mathrm{CC}_{50}\right)$ values of compounds that are cytotoxic in $50 \%$ were calculated using the GraphPad Prism software (version 5.01, GraphPad Software, San Diego, CA, USA) from the dose-response curves.

\subsubsection{CPE Inhibition Assay}

A549 cells were seeded together with different doses of tested compounds or DMSO (positive control) and infected with TBEV (Hypr strain; multiplicity of infection (MOI) of 0.1) for 96 h. CPE was measured by the colorimetric CytoTox $96^{\circledR}$ Non-Radioactive Cytotoxicity Assay (Promega, Madison, WI, USA) according to the manufacturer's instructions. One-way ANOVA with Dunnett's post-test was performed for statistical analysis using the GraphPad Prism software (version 5.01, GraphPad Software, San Diego, CA, USA).

\subsubsection{Plaque Assay}

Monolayers of A549 cells grown in 24-well culture plates were inoculated with 10-fold dilutions of TBEV strains for $2 \mathrm{~h}$ at $37{ }^{\circ} \mathrm{C}$. After the virus was removed, the cells were overlaid with carboxymethylcellulose in Modified Eagle's Medium (MEM) medium. After 5 days the medium was removed, the cells were washed with PBS and stained with the solution of $0.005 \%$ amido black to count the plaque-forming units (PFU). The virus titers were expressed in terms of PFU $/ \mathrm{mL}$. 


\subsubsection{Plaque Reduction Assay}

Monolayers of A549 cells seeded in 12-well plates were inoculated with TBEV at MOI of 0.001 . Virus inoculum was removed after $2 \mathrm{~h}$ at $37^{\circ} \mathrm{C}$, the cells were washed and overlaid with $1 \%$ carboxymethylcellulose in Modified Eagle's Medium (MEM) medium with DMSO or tested compounds. After three days, cells were washed with phosphate-buffered saline (PBS) and fixed with methanol. The infected virus foci were visualized by immunostaining with the monoclonal anti-Flavivirus group antigen antibody (4G2) (Absolute Antibody, Oxford, UK; diluted 1:1500 in PBS, 0,05\% Tween 80, 5\% FBS) as a primary antibody and anti-mouse secondary antibody conjugated with horseradish peroxidase (HRP) (diluted 1:2000) in PBS containing 0,05\% Tween 80 and 5\% FBS. Plaques were detected using a Vector Nova Red kit (Vector Laboratories Ltd., Peterborough, UK) according to the manufacturer's protocol and counted. If necessary, one-way ANOVA with Dunnett's post-test was performed in some experiments for statistical analysis using the GraphPad Prism software (version 5.01, GraphPad Software, San Diego, CA, USA).

\subsubsection{Dose-Response Antiviral Activity of Tested Compounds}

A549 cells were infected with TBEV Neudoerfl strain $(\mathrm{MOI}=0.1)$ and treated with different concentrations of the tested compounds $(0$ to $25 \mu \mathrm{M})$. Culture supernatants were collected two days post-infection and used for the estimation of viral titers using the plaque assay. The dose-response curves were prepared using GraphPad Prism software and used for calculations of the half-maximal inhibitory concentration $\left(\mathrm{IC}_{50}\right)$ values, indicating the concentration required to reduce the viral titer by $50 \%$ compared to the non-treated virus infected cells.

\subsubsection{Western Blot Analysis}

A monolayer of A549 cells in 12-well plates was inoculated with TBEV at an MOI of 0.1 for $2 \mathrm{~h}$. The virus was collected and fresh medium with different concentrations of compounds or DMSO was added and cultured for further $48 \mathrm{~h}$ at $37^{\circ} \mathrm{C}$. Cells were lysed at $4{ }^{\circ} \mathrm{C}$ for $1 \mathrm{~h}$ with TNET buffer (20 mM Tris- $\mathrm{HCl}$ (pH 7.4), $150 \mathrm{mM} \mathrm{NaCl}, 1 \mathrm{mM}$ EDTA, 1\% Triton X-100). Total concentration of proteins in lysates was measured using a Quick Start ${ }^{\mathrm{TM}}$ Bradford Protein Assay (Bio-Rad) according to the manufacturer's protocol. An amount of $50 \mu \mathrm{g}$ of proteins of each lysate were separated on a 10-20\% SDS-PAGE gel under denaturing and reducing conditions, transferred to PVDF membranes, and detected with a specific monoclonal anti-Flavivirus group antigen antibody (4G2) (1:1500 dilution) followed by anti-mouse peroxidase (HRP)-conjugated secondary antibodies (diluted 1:2000). Blots were developed using a Super Signal ${ }^{\mathrm{TM}}$ West Pico Plus Substrate system (Pierce, Dallas, TX, USA) using Chemidoc system Alliance ${ }^{\mathrm{TM}}$ Q9-Series (UVITEC, Cambrige, United Kingdom).

Author Contributions: Conceptualization, E.K. and G.P.-G.; methodology, E.K., G.B. and G.P.-G; investigation, E.K., G.B. and M.K.; writing — original draft preparation, E.K., G.B. and G.P.-G.; writing—review and editing, E.K., G.P.-G. and B.S.; visualization, G.B.; supervision, B.S.; project administration, E.K.; funding acquisition, E.K. All authors have read and agreed to the published version of the manuscript.

Funding: This research was funded by the National Science Centre, Poland, grant number UMO-2015/19/D/NZ6/01717. Ewelina Krol was the recipient of the fellowship L'Oréal - UNESCO For Women in Science.

Acknowledgments: We thank Karin Stiasny from the Center for Virology, Medical University of Vienna, Vienna, Austria for the TBEV Neudoerfl strain. We also thank Daniel Rưžek from Department of Virology, Veterinary Research Institute, Brno, Czech Republic for the TBEV Hypr strain.

Conflicts of Interest: The authors declare no conflict of interest.

\section{References}

1. Pierson, T.C.; Diamond, M.S. The continued threat of emerging flaviviruses. Nat. Microbiol. 2020, 5, 796-812. [CrossRef] [PubMed]

2. Pierson, T.C.; Diamond, M.S. The emergence of Zika virus and its new clinical syndromes. Nature 2018, 560, 573-581. [CrossRef] [PubMed] 
3. Chancey, C.; Grinev, A.; Volkova, E.; Rios, M. The global ecology and epidemiology of west Nile virus. Biomed. Res. Int. 2015, 2015, 376230. [CrossRef] [PubMed]

4. Faria, N.R.; Kraemer, M.U.G.; Hill, S.C.; Goes de Jesus, J.; Aguiar, R.S.; Iani, F.C.M.; Xavier, J.; Quick, J.; du Plessis, L.; Dellicour, S.; et al. Genomic and epidemiological monitoring of yellow fever virus transmission potential. Science 2018, 361, 894-899. [CrossRef]

5. Ruzek, D.; Avšič Županc, T.; Borde, J.; Chrdle, A.; Eyer, L.; Karganova, G.; Kholodilov, I.; Knap, N.; Kozlovskaya, L.; Matveev, A.; et al. Tick-borne encephalitis in Europe and Russia: Review of pathogenesis, clinical features, therapy, and vaccines. Antiviral Res. 2019, 164, 23-51. [CrossRef]

6. Tick-Borne Encephalitis-Annual Epidemiological Report for 2018. Available online: https://www.ecdc. europa.eu/en/publications-data/tick-borne-encephalitis-annual-epidemiological-report-2018 (accessed on 17 September 2020).

7. Dai, X.; Shang, G.; Lu, S.; Yang, J.; Xu, J. A new subtype of eastern tick-borne encephalitis virus discovered in Qinghai-Tibet Plateau, China. Emerg. Microbes Infect. 2018, 7, 74. [CrossRef]

8. Kovalev, S.Y.; Mukhacheva, T.A. Reconsidering the classification of tick-borne encephalitis virus within the Siberian subtype gives new insights into its evolutionary history. Infect. Genet. Evol. 2017, 55, 159-165. [CrossRef]

9. Růžek, D.; Dobler, G.; Mantke, O.D. Tick-borne encephalitis: Pathogenesis and clinical implications. Travel Med. Infect. Dis. 2010, 8, 223-232. [CrossRef]

10. Barrett, P.N.; Portsmouth, D.; Ehrlich, H.J. 34-Tick-borne encephalitis virus vaccines. In Vaccines, 6th ed.; Plotkin, S.A., Orenstein, W.A., Offit, P.A., Eds.; W.B. Saunders: London, UK, 2013; pp. 773-788.

11. Eyer, L.; Valdés, J.J.; Gil, V.A.; Nencka, R.; Hřebabecký, H.; Šála, M.; Salát, J.; Černý, J.; Palus, M.; De Clercq, E.; et al. Nucleoside inhibitors of tick-borne encephalitis virus. Antimicrob. Agents Chemother. 2015, 59, 5483-5493. [CrossRef]

12. Lenz, N.; Engler, O.; Grandgirard, D.; Leib, S.L.; Ackermann-Gäumann, R. Evaluation of antivirals against tick-borne encephalitis virus in organotypic brain slices of rat cerebellum. PLoS ONE 2018, 13, e0205294. [CrossRef]

13. Eyer, L.; Šmídková, M.; Nencka, R.; Neča, J.; Kastl, T.; Palus, M.; De Clercq, E.; Růžek, D. Structure-activity relationships of nucleoside analogues for inhibition of tick-borne encephalitis virus. Antiviral Res. 2016, 133, 119-129. [CrossRef] [PubMed]

14. Osolodkin, D.I.; Kozlovskaya, L.I.; Dueva, E.V.; Dotsenko, V.V.; Rogova, Y.V.; Frolov, K.A.; Krivokolysko, S.G.; Romanova, E.G.; Morozov, A.S.; Karganova, G.G.; et al. Inhibitors of tick-borne flavivirus reproduction from structure-based virtual screening. ACS Medicinal Chem. Lett. 2013, 4, 869-874. [CrossRef] [PubMed]

15. Krol, E.; Brzuska, G.; Szewczyk, B. Production and biomedical application of flavivirus-like particles. Trends Biotechnol. 2019, 0. [CrossRef] [PubMed]

16. Heinz, F.X.; Allison, S.L. Flavivirus structure and membrane fusion. Adv. Virus Res. 2003, 59, 63-97. [CrossRef]

17. Yoshii, K.; Yanagihara, N.; Ishizuka, M.; Sakai, M.; Kariwa, H. N-linked glycan in tick-borne encephalitis virus envelope protein affects viral secretion in mammalian cells, but not in tick cells. J. Gen. Virol. 2013, 94, 2249-2258. [CrossRef]

18. Pastuch-Gawolek, G.; Chaubey, B.; Szewczyk, B.; Krol, E. Novel thioglycosyl analogs of glycosyltransferase substrates as antiviral compounds against classical swine fever virus and hepatitis C virus. Eur. J. Med. Chem. 2017, 137, 247-262. [CrossRef]

19. Krol, E.; Wandzik, I.; Brzuska, G.; Eyer, L.; Růžek, D.; Szewczyk, B. Antiviral activity of uridine derivatives of 2-deoxy sugars against tick-borne encephalitis Virus. Molecules 2019, 24, 1129. [CrossRef]

20. Krol, E.; Pastuch-Gawolek, G.; Chaubey, B.; Brzuska, G.; Erfurt, K.; Szewczyk, B. Novel uridine glycoconjugates, derivatives of 4-aminophenyl 1-thioglycosides, as potential antiviral compounds. Molecules 2018, 23, 1435. [CrossRef]

21. Krol, E.; Wandzik, I.; Gromadzka, B.; Nidzworski, D.; Rychlowska, M.; Matlacz, M.; Tyborowska, J.; Szewczyk, B. Anti-influenza A virus activity of uridine derivatives of 2-deoxy sugars. Antiviral Res. 2013, 100, 90-97. [CrossRef]

22. Rajaram, H.; Palanivelu, M.K.; Arumugam, T.V.; Rao, V.M.; Shaw, P.N.; McGeary, R.P.; Ross, B.P. 'Click' assembly of glycoclusters and discovery of a trehalose analogue that retards A $\beta 40$ aggregation and inhibits A 340 -induced neurotoxicity. Bioorg. Med. Chem. Lett. 2014, 24, 4523-4528. [CrossRef]

23. Krawczyk, M.; Pastuch-Gawolek, G.; Mrozek-Wilczkiewicz, A.; Kuczak, M.; Skonieczna, M.; Musiol, R. Synthesis of 8-hydroxyquinoline glycoconjugates and preliminary assay of their $\beta 1,4$-GalT inhibitory and anti-cancer properties. Bioorg. Chem. 2019, 84, 326-338. [CrossRef] [PubMed] 
24. Pastuch-Gawolek, G.; Plesniak, M.; Komor, R.; Byczek-Wyrostek, A.; Erfurt, K.; Szeja, W. Synthesis and preliminary biological assay of uridine glycoconjugate derivatives containing amide and/or 1,2,3-triazole linkers. Bioorg. Chem. 2017, 72, 80-88. [CrossRef] [PubMed]

25. Xavier, N.M.; Lucas, S.D.; Jorda, R.; Schwarz, S.; Loesche, A.; Csuk, R.; Oliveira, M.C. Synthesis and Evaluation of the Biological Profile of Novel Analogues of Nucleosides and of Potential Mimetics of Sugar Phosphates and Nucleotides. Synlett. 2015, 26, 2663-2672. [CrossRef]

26. Rowan, A.S.; Nicely, N.I.; Cochrane, N.; Wlassoff, W.A.; Claiborne, A.; Hamilton, C.J. Nucleoside triphosphate mimicry: A sugar triazolyl nucleoside as an ATP-competitive inhibitor of B. anthracis pantothenate kinase. Org. Biomol. Chem. 2009, 7, 4029-4036. [CrossRef]

27. Ghosh, A.K.; Brindisi, M. Organic carbamates in drug design and medicinal chemistry. J. Med. Chem. 2015, 58, 2895-2940. [CrossRef]

28. Yang, Q.-R.; Qiao, W.-H.; Zhang, S.-M.; Qu, J.-P.; Liu, D.-L. Synthesis and characterization of a new cationic galactolipid with carbamate for gene delivery. Tenside Surfactants Deterg. 2010, 47, 294-299. [CrossRef]

29. Shin, I.; Jung, H.; Lee, M. Chemoselective ligation of maleimidosugars to peptides/protein for the preparation of neoglycopeptides/neoglycoprotein. Tetrahedron Lett. 2001, 42, 1325-1328. [CrossRef]

30. Ghirardello, M.; Ledru, H.; Sau, A.; Galan, M.C. Chemo-selective Rh-catalysed hydrogenation of azides into amines. Carbohydr. Res. 2020, 489, 107948. [CrossRef]

31. Pastuch-Gawołek, G.; Malarz, K.; Mrozek-Wilczkiewicz, A.; Musioł, M.; Serda, M.; Czaplinska, B.; Musiol, R. Small molecule glycoconjugates with anticancer activity. Eur. J. Med. Chem. 2016, 112, 130-144. [CrossRef]

32. Mereyala, H.B.; Gurrala, S.R. A highly diastereoselective, practical synthesis of allyl, propargyl 2,3,4,6-tetra-O-acetyl- $\beta$-d-gluco, $\beta$-d-galactopyranosides and allyl, propargyl heptaacetyl- $\beta$-d-lactosides. Carbohydr. Res. 1998, 307, 351-354. [CrossRef]

33. Sheehan, J.C.; Hess, G.P. A new method of forming peptide bonds. J. Am. Chem. Soc. 1955, 77, $1067-1068$. [CrossRef]

34. Kolb, H.C.; Finn, M.G.; Sharpless, K.B. Click chemistry: Diverse chemical function from a few good reactions. Angew. Chem. Int. Ed. 2001, 40, 2004-2021. [CrossRef]

35. Liang, L.; Astruc, D. The copper(I)-catalyzed alkyne-azide cycloaddition (CuAAC) "click" reaction and its applications. An overview. Coord. Chem. Rev. 2011, 255, 2933-2945. [CrossRef]

36. Krol, E.; Wandzik, I.; Szeja, W.; Grynkiewicz, G.; Szewczyk, B. In vitro antiviral activity of some uridine derivatives of 2-deoxy sugars against classical swine fever virus. Antiviral Res. 2010, 86, 154-162. [CrossRef]

37. Krol, E.; Wandzik, I.; Krejmer-Rabalska, M.; Szewczyk, B. Biological evaluation of uridine derivatives of 2-deoxy sugars as potential antiviral compounds against influenza A virus. Int. J. Mol. Sci. 2017, 18, 1700. [CrossRef]

38. Routhu, N.K.; Lehoux, S.D.; Rouse, E.A.; Bidokhti, M.R.M.; Giron, L.B.; Anzurez, A.; Reid, S.P.; Abdel-Mohsen, M.; Cummings, R.D.; Byrareddy, S.N. Glycosylation of Zika virus is important in host-virus interaction and pathogenic potential. Int. J. Mol. Sci. 2019, 20, 5206. [CrossRef]

39. Martina, B.E.E.; Koraka, P.; van den Doel, P.; Rimmelzwaan, G.F.; Haagmans, B.L.; Osterhaus, A.D.M.E. DC-SIGN enhances infection of cells with glycosylated West Nile virus in vitro and virus replication in human dendritic cells induces production of IFN-alpha and TNF-alpha. Virus Res. 2008, 135, 64-71. [CrossRef]

40. Goo, L.; DeMaso, C.R.; Pelc, R.S.; Ledgerwood, J.E.; Graham, B.S.; Kuhn, R.J.; Pierson, T.C. The Zika virus envelope protein glycan loop regulates virion antigenicity. Virology 2018, 515, 191-202. [CrossRef]

41. Davis, C.W.; Mattei, L.M.; Nguyen, H.-Y.; Ansarah-Sobrinho, C.; Doms, R.W.; Pierson, T.C. The location of asparagine-linked glycans on West Nile virions controls their interactions with CD209 (dendritic cell-specific ICAM-3 grabbing nonintegrin). J. Biol. Chem. 2006, 281, 37183-37194. [CrossRef]

42. Hacker, K.; White, L.; de Silva, A.M. N-linked glycans on dengue viruses grown in mammalian and insect cells. J. Gen. Virol. 2009, 90, 2097-2106. [CrossRef]

43. Khoo, U.-S.; Chan, K.Y.K.; Chan, V.S.F.; Lin, C.L.S. DC-SIGN and L-SIGN: The SIGNs for infection. J. Mol. Med. (Berl) 2008, 86, 861-874. [CrossRef] [PubMed]

44. Carbaugh, D.L.; Baric, R.S.; Lazear, H.M. Envelope protein glycosylation mediates Zika virus pathogenesis. J. Virol. 2019, 93. [CrossRef] [PubMed]

45. Goto, A.; Yoshii, K.; Obara, M.; Ueki, T.; Mizutani, T.; Kariwa, H.; Takashima, I. Role of the N-linked glycans of the prM and $\mathrm{E}$ envelope proteins in tick-borne encephalitis virus particle secretion. Vaccine 2005, 23, 3043-3052. [CrossRef] [PubMed] 
46. Mossenta, M.; Marchese, S.; Poggianella, M.; Slon Campos, J.L.; Burrone, O.R. Role of N-glycosylation on Zika virus E protein secretion, viral assembly and infectivity. Biochem. Biophys. Res. Commun. 2017, 492, 579-586. [CrossRef] [PubMed]

47. Hanna, S.L.; Pierson, T.C.; Sanchez, M.D.; Ahmed, A.A.; Murtadha, M.M.; Doms, R.W. N-linked glycosylation of West Nile Virus envelope proteins influences particle assembly and infectivity. J. Virol. 2005, 79, 13262-13274. [CrossRef] [PubMed]

48. Lorenz, I.C.; Kartenbeck, J.; Mezzacasa, A.; Allison, S.L.; Heinz, F.X.; Helenius, A. Intracellular assembly and secretion of recombinant subviral particles from tick-borne encephalitis Virus. J. Virol. 2003, 77, 4370-4382. [CrossRef]

49. Lattová, E.; Straková, P.; Pokorná-Formanová, P.; Grubhoffer, L.; Bell-Sakyi, L.; Zdráhal, Z.; Palus, M.; Ruzek, D. Comprehensive $N$-glycosylation mapping of envelope glycoprotein from tick-borne encephalitis virus grown in human and tick cells. Sci. Rep. 2020, 10, 13204. [CrossRef]

50. Epp, J.B.; Widlanski, T.S. Facile preparation of nucleoside-5'-carboxylic acids. J. Org. Chem. 1999, 64, $293-295$. [CrossRef]

51. Winans, K.A.; Bertozzi, C.R. An Inhibitor of the human UDP-GlcNAc 4-epimerase identified from a uridine-based library: A Strategy to inhibit O-linked glycosylation. Chem. Biol. 2002, 9, 113-129. [CrossRef]

52. Hwu, J.R.; Jain, M.L.; Tsai, F.-Y.; Tsay, S.-C.; Balakumar, A.; Hakimelahi, G.H. Ceric ammonium nitrate on silica gel for efficient and selective removal of trityl and silyl groups. J. Org. Chem. 2000, 65, 5077-5088. [CrossRef]

Publisher's Note: MDPI stays neutral with regard to jurisdictional claims in published maps and institutional affiliations. 